CRREL

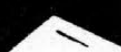

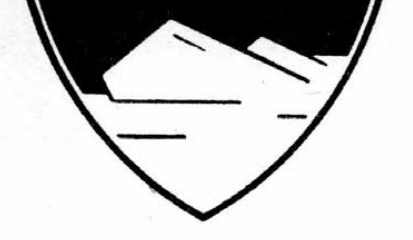

\section{Research Repart 112}

NOVEMBER, 1964

\title{
Age Hardening of Snow at the South Pole
}

by

\author{
Anthony J. Gow \\ and \\ Rene O. Ramseier
}

U.S. ARMY MATERIEL COMMAND

COLD REGIONS RESEARCH \& ENGINEERING LABORATORY HANOVER, NEW HAMPSHIRE

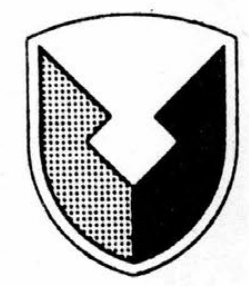




\section{PREFACE}

Work on this project was performed for the Materials Research Branch of the Research Division, Mr. James A. Bender, Chief.

The project was co-sponsored by the United States Antarctic Research Program and supported in part by a National Science Foundation grant to the U. S. Army Cold Regions Research and Engineering Laboratory. The U. S. Navy provided valuable logistic support in the field.

The authors wish to thank James B. Burnham, National Bureau of Standards, ionosphere physicist, at the Pole for his assistance in the field work. The enthusiastic interest and recommendations made by James A. Bender, Division Chief, are very much appreciated.

This report has been reviewed and approved for publication by Headquarters, U. S. Army Materiel Command.

Manuscript received 3 April 1964. 

AD
Accession No.

U. S. Army Cold Regions Research and Engineering Laboratory, Army Materiel Command, Hanover, N.H. AGE HARDENING OF SNOW AT THE SOUTH POLEAnthony J. Gow, and René O. Ramseier

Research Report 112, Nov 1964, 19p-illus, -table-app. DA Task 8X99-27-001-03

Unclassified Report

The age hardening of artificially and naturally compacted snow has been investigated at the South Pole.

Results show that the age-hardening process is greatly retarded at low temperatures. Artificially compacted samples of density $0.55 \mathrm{~g} / \mathrm{cm}^{3}$ attained a compressive at $-49 \mathrm{C}$ Exposure to $\mathrm{kg} / \mathrm{cm}^{2}$ after one year's aging age hardening. Irradiated samples attained a tren of $6.0 \mathrm{~kg} / \mathrm{cm}^{2}$. Irer $100 \mathrm{~h}$, increas attained a strength maximum of $8.0 \mathrm{~kg} / \mathrm{cm}^{2}$ at the ensing to a virtual ipressive strength particle size and with increasing angularity of snowicles. Below isnow wes fou the snow was found to increase rapidly with increase in density. Naturally compacted snow of density 0.55 of the age-hardened samples of artificially compacted (over)

U. S. Army Cold Regions Research and Engineering Laboratory, Army Materiel Command, Hanover, N.H. AGE HARDENING OF SNOW A T THE SOUTH POLEAnthony J. Gow, and René O. Ramseier

Research Report 112, Nov 1964, 19p-illus,-table-app. DA Task 8X99-27-001-03

Unclassified Report

The age hardening of artificially and naturally compacted snow has been investigated at the South Pole. Results show that the age-hardening process is greatly retarded at low temperatures. Artificially compacted samples of density $0.55 \mathrm{~g} / \mathrm{cm}^{3}$ attained a compressive istrength of less than $3.0 \mathrm{~kg} / \mathrm{cm}^{2}$ after one year's aging at -49. Exposure to solar radiation accelerated the age hardening. Ir radiated samples attained a strength of $0.0 \mathrm{~kg} / \mathrm{cm}^{2}$ after $100 \mathrm{hr}$, increasing to a virtual maximum of $8.0 \mathrm{~kg} / \mathrm{cm}^{2}$ at the end of $600 \mathrm{hr}$. Compressive strengths increased with decrease in snowparticle size and with increasing angularity of the partiicles. Below $3 \mathrm{~m}$ the strength of naturally compacted snow was found to increase rapidly with increase in density. Naturally compacted snow of density 0.55 $\mathrm{g} / \mathrm{cm}^{3}$ possessed considerably greater strength than an of the age-hardened samples of artificially compacted (over)

\section{UNC LASSIFIED}

1. Snow (Construction Material)

2. Snow--Strength-Measurement

3. Snow samplers-Antarctic regions

Gow, Anthony J.

II. Ramseier, René O.

III. U. S. Army Cold R

Research and Engion ing Laboratory

\section{UNC LASSIFIED}

1. Snow (Construction Material

2. Snow--Strength-Measurement

3. Snow samplers Antarctic regions

I. Gow, Anthony J

II. Ramseier, René O.

III. U. S. Army Cold Regions Research and En ing Laborator
$\mathrm{AD}$

Accession No.

U. S. Army Cold Regions Research and Engineering Laboratory, Army Materiel Command, Hanover, N. AGE HARDENING OF SNOW AT THE SOUTH POLEAnthony J. Gow, and René O. Ramseier

Research Report 112, Nov 1964, 19p-illus. -table-app. DA Task 8X99-27-001-03

Unclassified Report

The age hardening of artificially and naturally com-

pacted snow has been investigated at the South Pole.

Results show that the age-hardening process is greatly retarded at low temperatures. Artificially compacted samples of density $0.55 \mathrm{~g} / \mathrm{cm}^{3}$ attained a compressive strength of less than $3.0 \mathrm{~kg} / \mathrm{cm}^{2}$ after one year's agin at $-49 \mathrm{C}$. Exposure to solar radiation accelerated the age hardening. Ir radiated samples attained a strength of $6.0 \mathrm{~kg} / \mathrm{cm}^{2}$ after $100 \mathrm{hr}$, increasing to a virtual maximum of $8.0 \mathrm{~kg} / \mathrm{cm}^{2}$ at the end of $600 \mathrm{hr}$. Compressive strengths increased with decrease in snowparticle size and with increasing angularity of the parti; cles. Below $3 \mathrm{~m}$ the strength of naturally compacted snow was found to increase rapidly with increase in density. Naturally compacted snow of density 0.55 g/cm possessed considerably greater strength than an of the age-hardened samples of artificially compacted

AD
(over)

Accession No.

U. S. Army Cold Regions Research and Engineering Laboratory, Army Materiel Command, Hanover, N.H. AGE HARDENING OF SNOW AT THE SOUTH POLEAnthony J. Gow, and René O. Ramseier

Research Report 112, Nov 1964, 19p-illus.-table-app. DA Task 8X99-27-001-03 Unclassified Report

The age hardening of artificially and naturally compacted snow has been investigated at the South Pole. Results show that the age-hardening process is greatly "retarded at low temperatures. Artificially compacted samples of density $0.55 \mathrm{~g} / \mathrm{cm}^{3}$ attained a compressive istrength of less than $3.0 \mathrm{~kg} / \mathrm{cm}^{2}$ after one year's aging at $-49 \mathrm{C}$. Exposure to solar radiation accelerated the age hardening. Irradiated samples attained a strength of $6.0 \mathrm{~kg} / \mathrm{cm}^{2}$ after $100 \mathrm{hr}$ increasing to a virtual maximum of $8.0 \mathrm{~kg} / \mathrm{cm}^{2}$ at the pressive strengths increased with decrease in comparticle size and with increasing angularity of the particles. Below $3 \mathrm{~m}$ the cles. density Naturally compacted snow of derease in . $/ \mathrm{cm}^{3}$ possessed considerably greater streng than of the age-hardened samples of artificially compacted
UNC LASSIFIED

1. Snow (Construction Material)

2. Snow--Strength-Measurement

3. Snow samplers Antarctic region

I. Gow, Anthony J

II. Ramseier, René $O$.

III. U. S. Army Cold Regions Research and Engineer ing Laboratory

\section{UNC LASSIFIED}

1. Snow (Construction Material)

2. Snow--Strength-Measurement

3. Snow samplers-Antarctic region

I. Gow, Anthony J.

II. Ramseier, René $O$.

III. U. S. Army Cold Regions Research and Engineering Laboratory (over) 


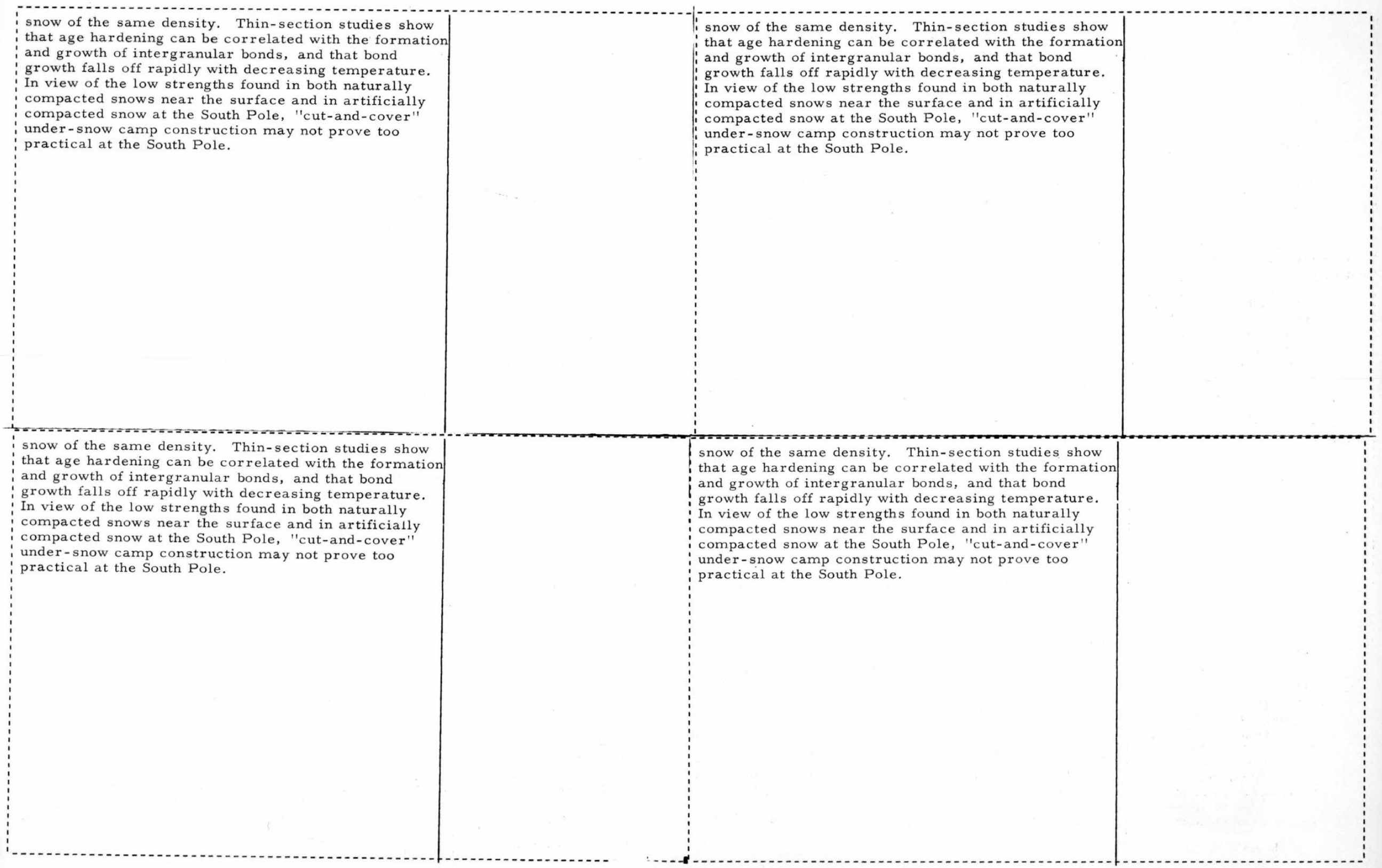




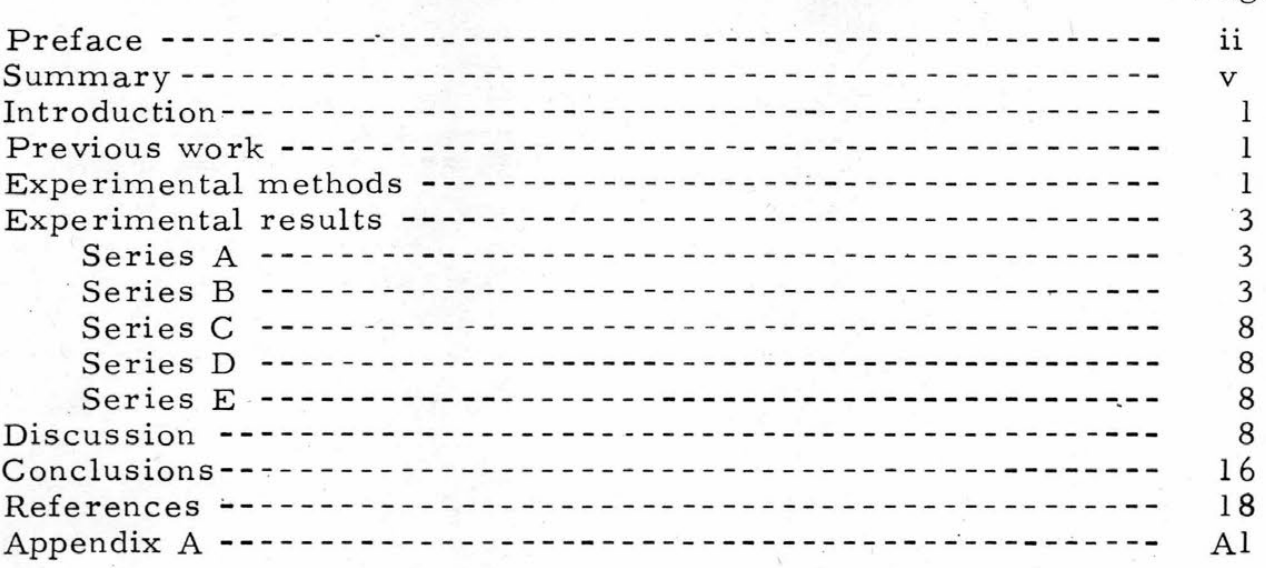

\section{ILLUSTRATIONS}

Figure

1. Snow temperature profiles at the South Pole

2. Grain-size analyses of disaggregated snow-..-..-.-- 2

3. Compaction apparatus used for preparing cylindrical

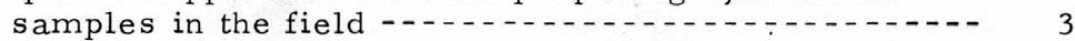

4. Experimental set-up in snow mine at the South Pole ----- 4

5. Unconfined compressive strength of snow cylinders, series A - 5

6. Thin-section photographs of age-hardened structure, series A

7. Daily average ambient air temperatures, 18 Dec 1960 to 20 Jan 1961

8. Unconfined compressive strength of snow cylinders,

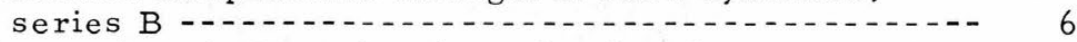

9. Thin-section photographs of age-hardened structure, series B -...- 7

10. Cross-sectional area loss by sublimation of snow

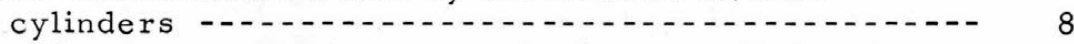

11. Unconfined compressive strength of snow cylinders, series C

12. Thin-section photographs of age-hardened structure,

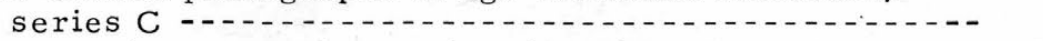

13. Compressive strength as a function of particle size, series D - 10

14. Thin-section photographs of age-hardened structure,

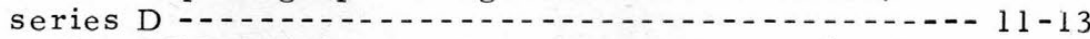

15. Strength vs density of naturally compacted snow (series

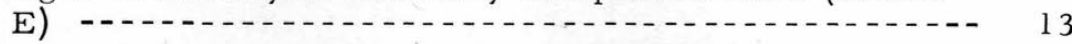

16. Thin-section photographs of the grain structure of naturally compacted snow (series E) at the South Pole 14

17. Age-hardening curves -17

\section{T ABLES}

Table

I. Parameters used to fit data

AI. Unconfined compressive strength as a function of aging of snow cylinders at $-49.4 \mathrm{C}$ 


\section{CONTENTS (Cont'd)}

Table

AII. Unconfined compressive strength as a function of aging of snow cylinders at ambient temperature exposed to solar

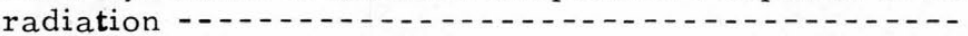

AIII. Unconfined compressive strength as a function of aging of snow cylinders at ambient air temperature protected from solar radiation -......

Page

AIV. Unconfined compressive strength as a function of snow
particle size of snow cylinders at ambient air tem-
perature protected from solar radiation-

AIV. Unconfined compressive strength as a function of snow
particle size of snow cylinders at ambient air tem-
perature protected from solar radiation-

AIV. Unconfined compressive strength as a function of snow
particle size of snow cylinders at ambient air tem-
perature protected from solar radiation-

AV. Unconfined compressive strength as a function of depth and density of snow cylinders 


\section{SUMMARY}

The age hardening of artificially and naturally compacted snow has been investigated at the South Pole. Results show that the age-hardening process is greatly retarded at low temperatures. Artificially compacted samples of density $0.55 \mathrm{~g} / \mathrm{cm}^{3}$ attained a compressive strength of less than $3.0 \mathrm{~kg} / \mathrm{cm}^{2}$ after one year's aging at $-49 \mathrm{C}$. Exposure to solar radiation accelerated the age hardening. Irradiated samples attained a strength of $6.0 \mathrm{~kg} / \mathrm{cm}^{2}$ after $100 \mathrm{hr}$, increasing to a virtual maximum of $8.0 \mathrm{~kg} / \mathrm{cm}^{2}$ at $600 \mathrm{hr}$. Compressive strengths increased with a decrease in snow-particle size and with an increasing angularity of the particles. Below $3 \mathrm{~m}$ the strength of naturally compacted snow was found to increase rapidly with an increase in density. Naturally compacted snow of density $0.55 \mathrm{~g} / \mathrm{cm}^{3}$ possessed considerably greater strength than any of the age-hardened samples of artificially compacted snow of the same density. Thin-section studies show that age hardening can be correlated with the formation and growth of intergranular bonds, and that bond growth falls off rapidly with decreasing temperature. In view of the low strength found in both naturally and artificially compacted snow at the South Pole, "cut-and-cover" undersnow camp construction may not prove practical at the South Pole. 


\section{AGE HARDENING OF SNO'W AT THE SOUTH POLE}

by

Anthony J. Gow and Rene O. Ramseier

Introduction

The object of this report is to present the results of some recent studies of the age hardening of artificially and naturally compacted snows at the South Pole. Prior to this study very little was known as to the rate of age hardening or the ultimate strength of snow at very low temperatures. In view of the proposed construction of a new camp under the snow at the South Pole, such data are most desirable. Undersnow construction was successfully accomplished by the U. S. Army in Greenland, and it is hoped that the same methods can be applied in the Antarctic. In the present investigations, an attempt was made to prepare snow samples which simulated, in density and grain size, the disaggregated snow produced by the Peter snow miller and used extensively in undersnow camp construction. Of particular interest was the evaluation of the effect of very low temperatures at the South Pole on the age-hardening process. The effects of solar radiation, grain size, and grain shape on the age hardening of snow were also investigated. These investigations were supplemented by thin-section studies to determine changes in the structure of the snow as it aged.

Previous work

Extensive tests on the strength properties of snow have been made by Butkovich (1956). These investigations, conducted primarily on old snow that had reached its maximum strength over a long period of time, showed that the compressive strength of the snow increased as a linear function of the density. Studies of age hardening of disaggregated snow (the increase of strength with time) by Bender (1957) indicated that the strength of bonds between grains in test samples increased very rapidly during the first 4 days and attained close to maximum strength in 10 days. In 1957 Jellinek carried out more detailed studies of the compressive strength of artificially compacted snow cylinders as a function of age of the snow, snow-particle size, and amount of age hardening. His results show that young snow hardens (strengthens) more rapidly than old snow under the same conditions of aging, and that the ultimate strength of his particular snow (aged 168 hours) diminished with decrease in grain size. Field studies on the changes in snow structures with aging have been reported by Fuchs $(1959,1960)$, Butkovich (1962), and Wuori (1962). All these studies indicate that age hardening of snow involves the formation of bonds between grains, and that the strength of the snow seems to be largely determined by the number and size of intergranular bonds. Koch and Wegener (1930) used this principle in their north Greenland expedition in 1913. They mixed ice chips with snow to build bridges across crevasses which could be crossed by horses and sledges the following day. Recently, Kingery (1960) and Kuroiwa (1961) have compared the kinetics of the freezing together of ice particles (and the resultant formation of bonds) with those derived from sintering phenomena. All the above studies were performed at temperatures varying from -7 to $-20 \mathrm{C}$, and the object of the present study was to extend current knowledge of age hardening to the low-temperature conditions prevailing at the South Pole.

\section{Experimental methods}

Cylindrical snow samples used in the age-hardening studies were all prepared from a standard mixture of disaggregated snow. A $4-\mathrm{m}$ pit was dug for this purpose on 6 December 1960. A preliminary study of the pit stratigraphy showed that snow now buried to a depth of $4 \mathrm{~m}$ was deposited at the surface 21 years ago. This gives an accumulation rate of about $7.4 \mathrm{~cm}$ of water per year. Densities varied considerably from layer to layer. The density averaged $0.36 \mathrm{~g} / \mathrm{cm}^{3}$ in the first meter and increased to $0.42 \mathrm{~g} / \mathrm{cm}^{3}$ at $4-\mathrm{m}$ depth. The temperature varied from $-30 \mathrm{C}$ in the surface layers to $-47 \mathrm{C}$ at $4 \mathrm{~m}$. Temperature profiles for the late summer and fall from the surface to $10 \mathrm{~m}$ are given in Figure 1. 


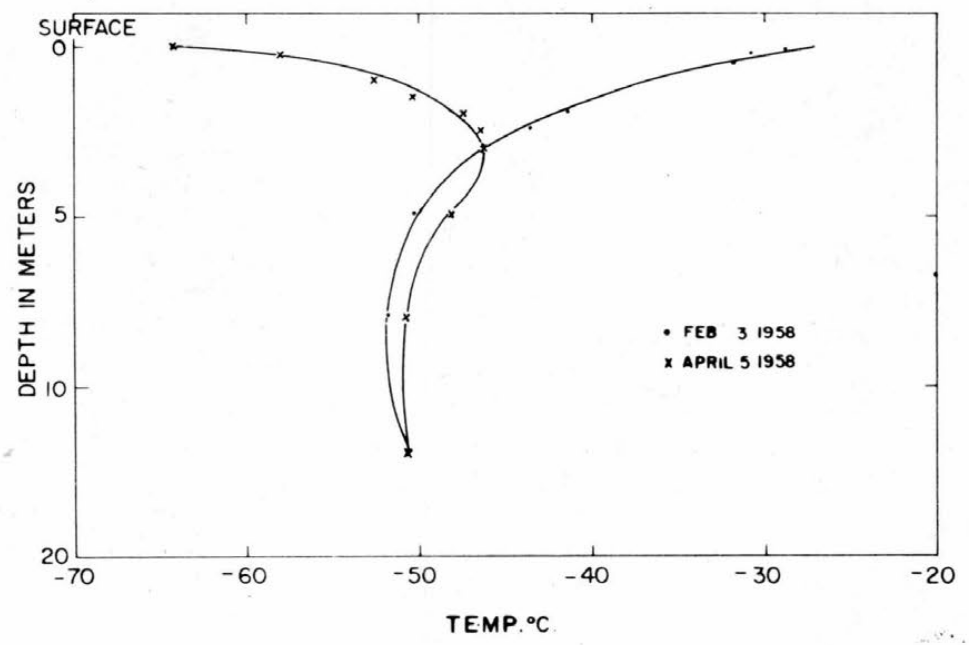

Figure 1. Snow temperature profiles at the South Pole. (After Giovinetto, 1960)

Blocks of snow were cut in continuous vertical sequence from one wall of the pit and disaggregated on a large sieve of $1.0-\mathrm{mm}$ mesh. All grains larger than $1.0 \mathrm{~mm}$ were discarded and the remainder were thoroughly mixed to form the standard sample material. Results of sieve analyses of two arbitrary samples from this snow mixture are given in Figure 2 . These curves compare rather closely with the size distributions observed in well-sorted, medium-to coarse-grained sands.

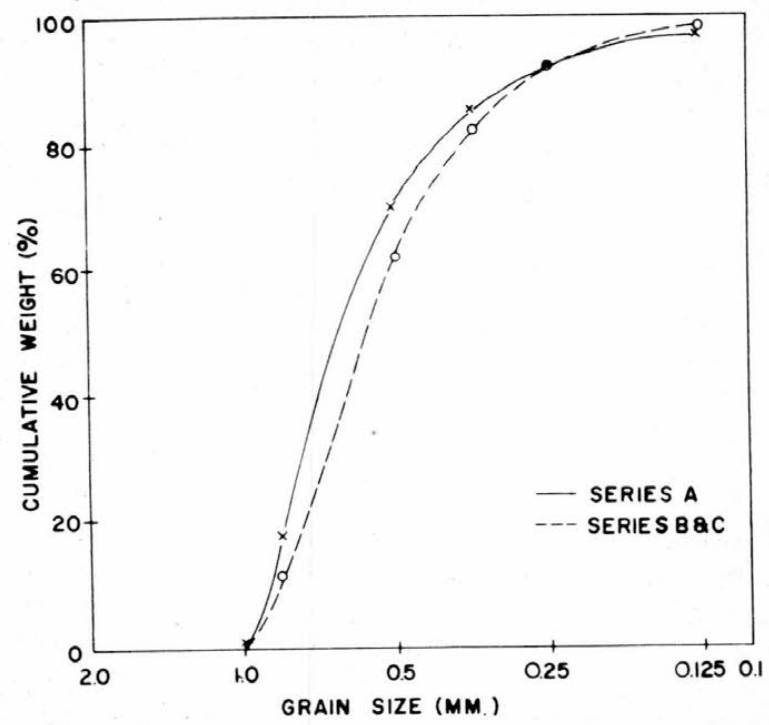

Figure 2. Grain-size analyses of disaggregated snow.

The compaction apparatus for making the snow test cylinders consisted of two half cylinders of aluminum coated on the inside with Teflon (Fig. 3). The two half cylinders were assembled and mounted on a circular base plate, and the snow was added in small 


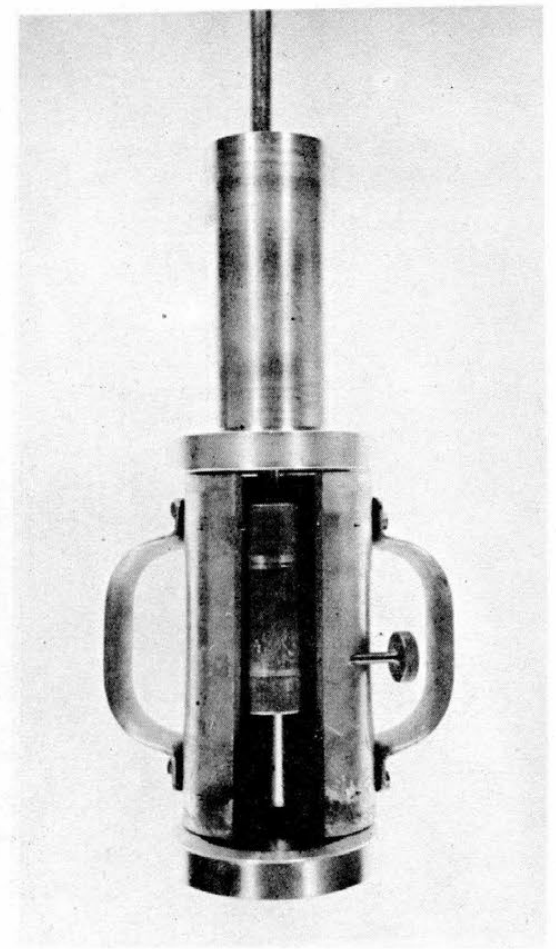

Figure 3. Compaction apparatus used for preparing cylindrical samples in the field.

amounts and tamped periodically with an aluminum plunger. After compaction the two half cylinders were disconnected, and the artificially compressed snow cylinder $(5.7 \mathrm{~cm}$ diam, $20.0 \mathrm{~cm}$ long) was carefully removed. With this method it was possible to prepare test samples of almost constant density $\left(0.554 \pm 0.005 \mathrm{~g} / \mathrm{cm}^{3}\right)$ at a rate of about 40 cylinders per hour. Several series of snow cylinders were prepared and subjected to aging under varied conditions. Each series consisted of 8 to 13 groups of samples, and each group contained 8 to 10 samples. At intervals throughout the aging process, groups of samples were crushed in unconfined compression on a Soiltest press with a 2000-1b (900-kg) load capacity (Fig. 4). The upper plate of the press could be swiveled through an angle of about $5 \mathrm{deg}$ to accommodate slight irregularities in the bearing surface of the snow cylinder. The force required to crush a sample was read from a dial gage mounted on the proving ring. The load was applied manually at a rate of about $10.5 \mathrm{~kg} / \mathrm{cm}^{2}$ -

sec. The cylinder usually fractured into three pieces in the manner described by Butkovich (1956). However, many of the low-strength samples (those aged for a short period of time) tended to crumble rather than fracture. All samples used in the present study were processed during December 1960 and most of the tests were completed before the authors left the South Pole in late January 1961 . However, extra samples were prepared in December 1960 to permit continuation of some of the low-temperature tests during the winter of 1961. The authors are indebted to Mr. James Burnham, ionospheric physicist at the South Pole in 1961, for conducting these additional tests on the series A samples.

Changes in structure of snow with aging were investigated in thin sections. The aniline method for the preparation of thin sections as described by Kinosita and Wakahama (1960) was used. Thin sections were cut to a thickness of about $0.1 \mathrm{~mm}$ on a sledge microtome, and photomicrographs were obtained in transmitted light and between crossed polaroids with an extension camera.

Experimental Results

Series A. The samples for series A were prepared and aged in a $27.5 \mathrm{~m} \mathrm{deep}$ snow mine at a temperature of $-49.4 \pm 0.2 \mathrm{C}$. Each point in Figure 5 represents the average unconfined compressive strength of ten samples. A full tabulation of the results of these very low temperature age-hardening tests is given in Table AI of Appendix A. Two photographs of the structure of the snow as seen in thin section are given in Figure 6.

Series B. The samples in series B were aged at the snow surface, i. e. subjected to solar radiation at the ambient air temperature (Fig. 7). Results are presented in Figure 8 and Table AII. Thin-section photographs are given in Figure 9. During aging, the series B samples underwent progressive sublimation. In Figure 10 sublimation is shown in terms of cross-sectional area loss plotted against time for both series $B$ and $C$. 


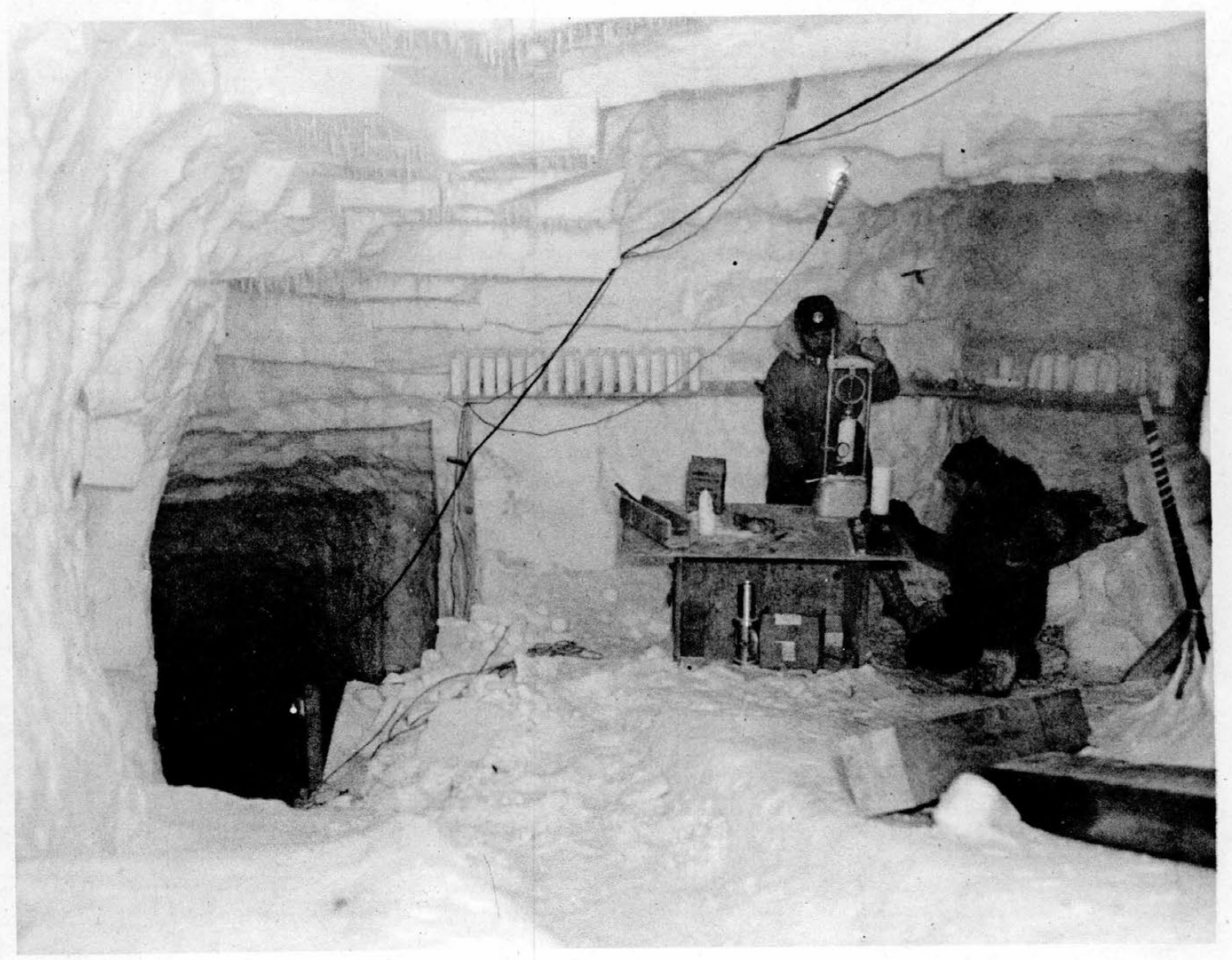

Figure 4. Experimental set-up in snow mine at the South Pole. Samples from series $E$ (on bench at right) being crushed in the soil test press. Series A samples can be seen on shelf at left. The temperature in this part of the snow mine is $-49 \mathrm{C}$. 


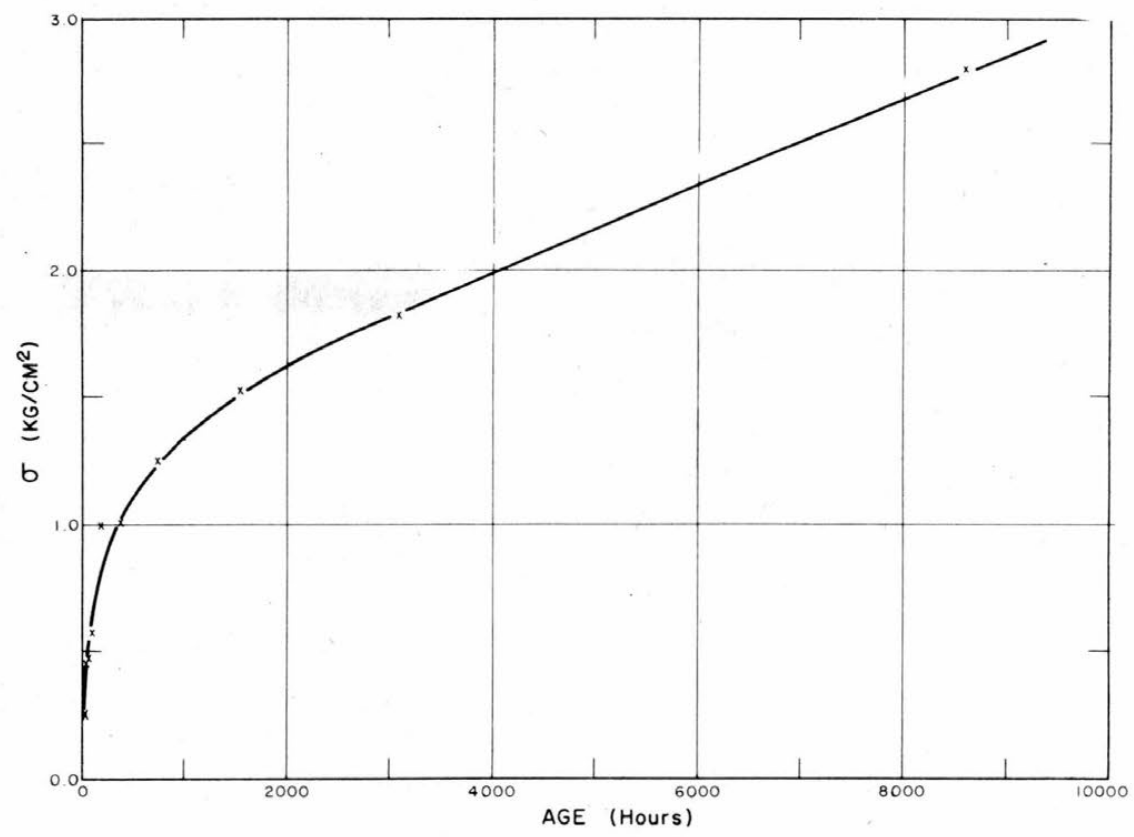

Figure 5. Unconfined compressive strength of snow cylinders as a function of the age of the cylinders at -49C. Each point represents the average of ten tests in series A.

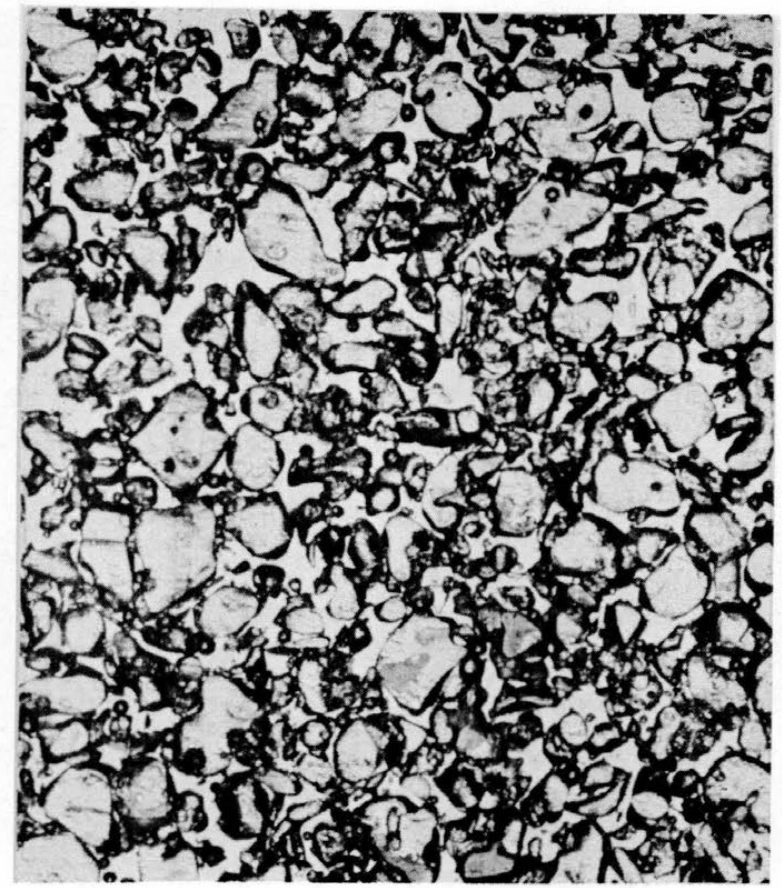

a) after $768 \mathrm{hr}$

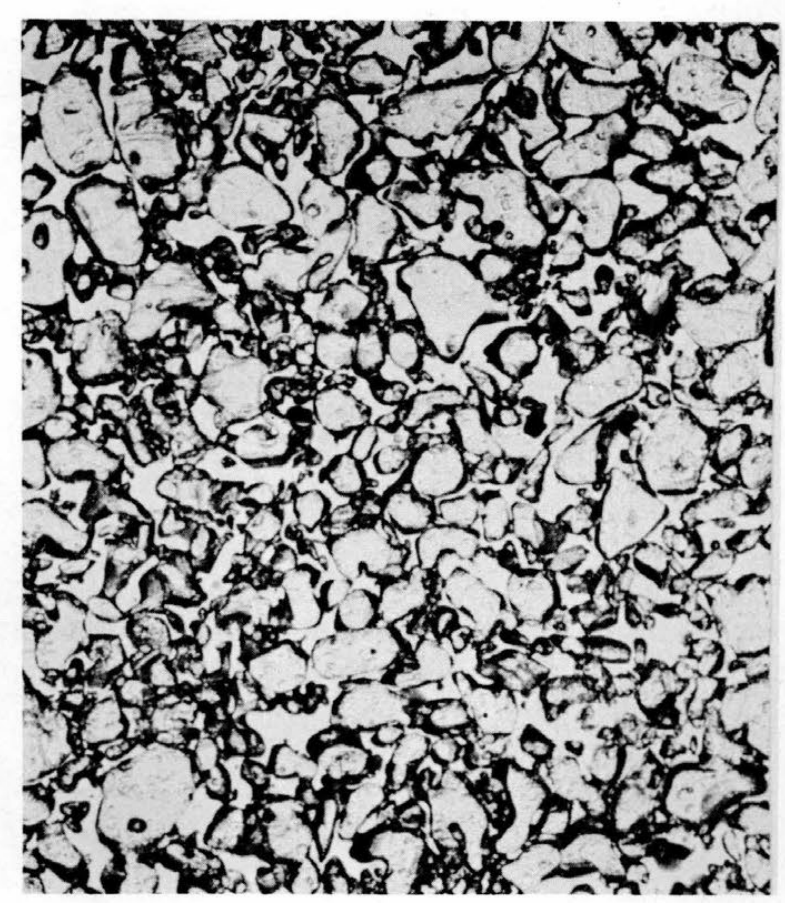

b) after i year

Figure 6. Thin-section photographs of age-hardened structure in series A samples. 9X magnification. Note how weakly developed the bonding is even after one year's aging. 


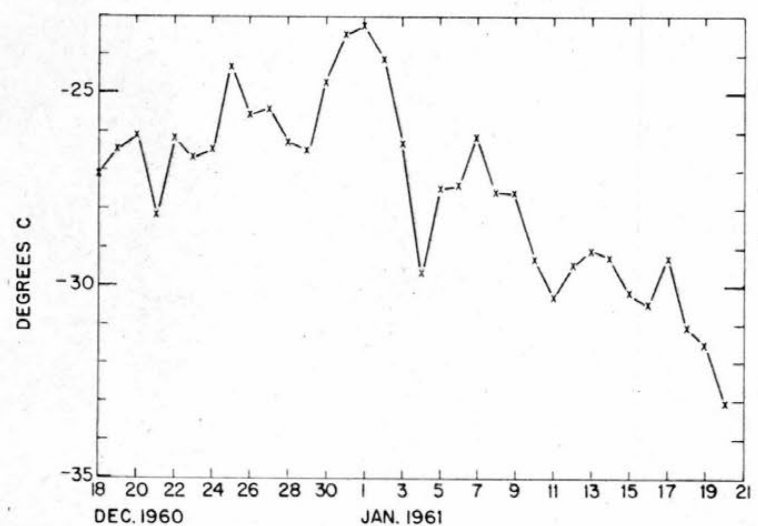

Figure 7. Plot of daily average ambient air temperatures $3 \mathrm{ft}(0.9 \mathrm{~m})$ above the snow surface from 18 December 1960 to 20 January 1961 at the South Pole.

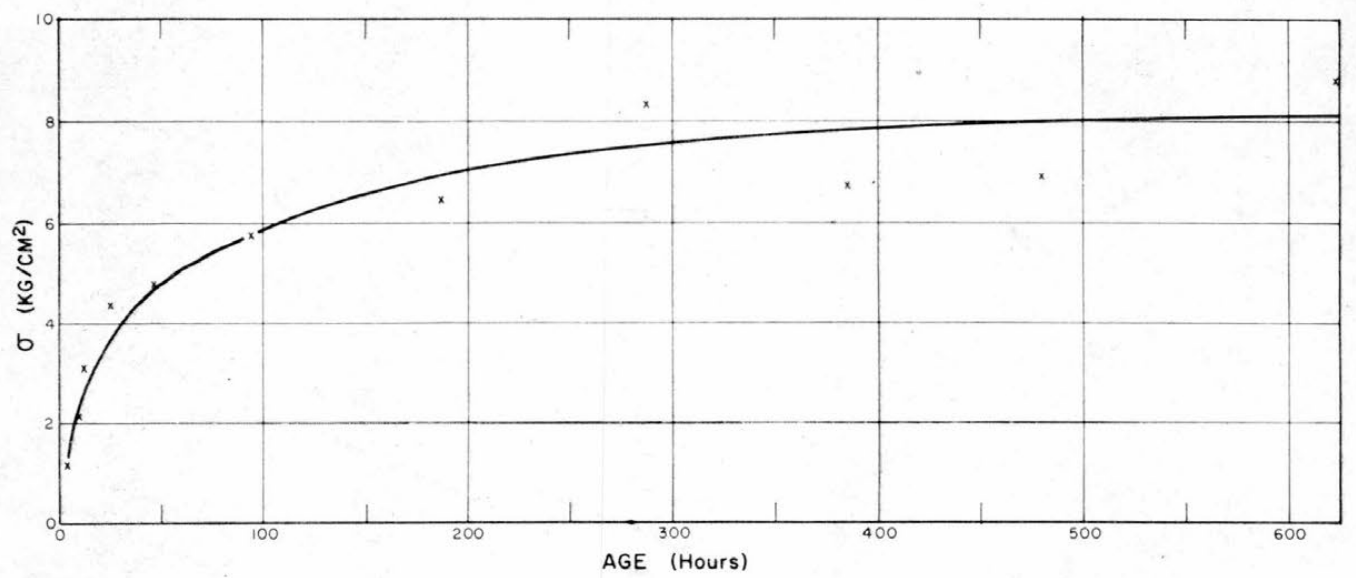

Figure 8. Unconfined compressive strengths of snow cylinders of series B. Each point represents the average of ten tests. 


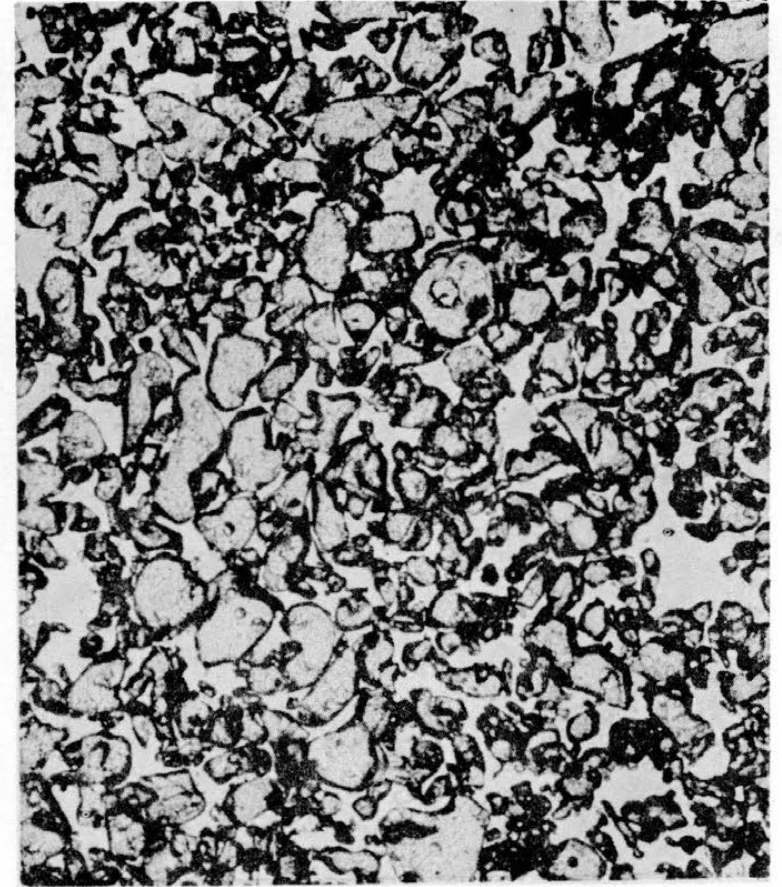

a) after $48 \mathrm{hr}$

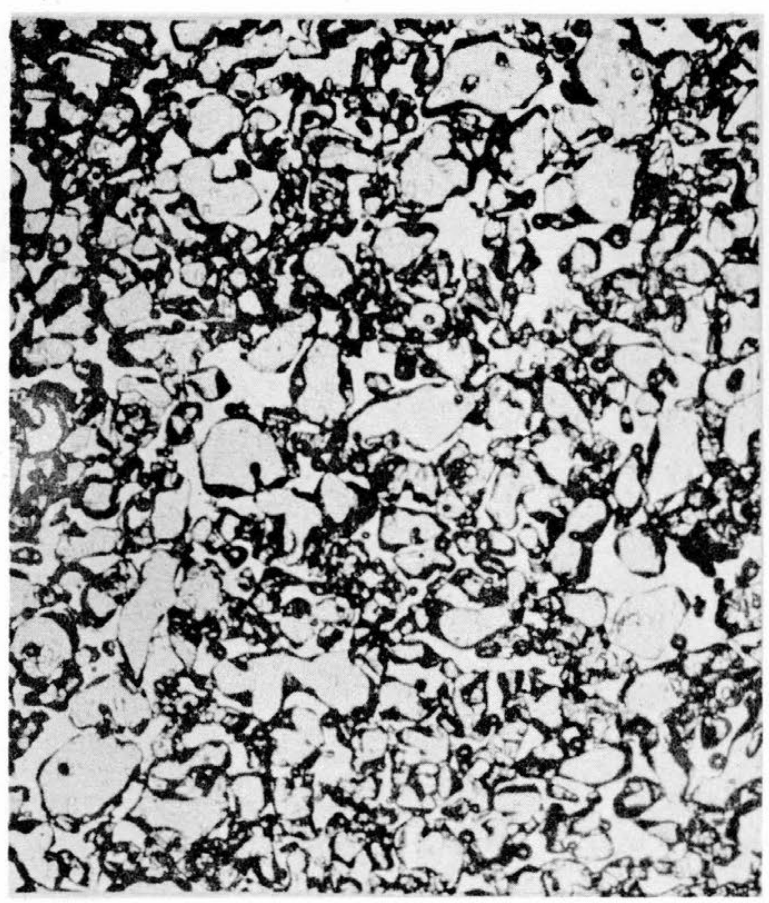

b) after $96 \mathrm{hr}$

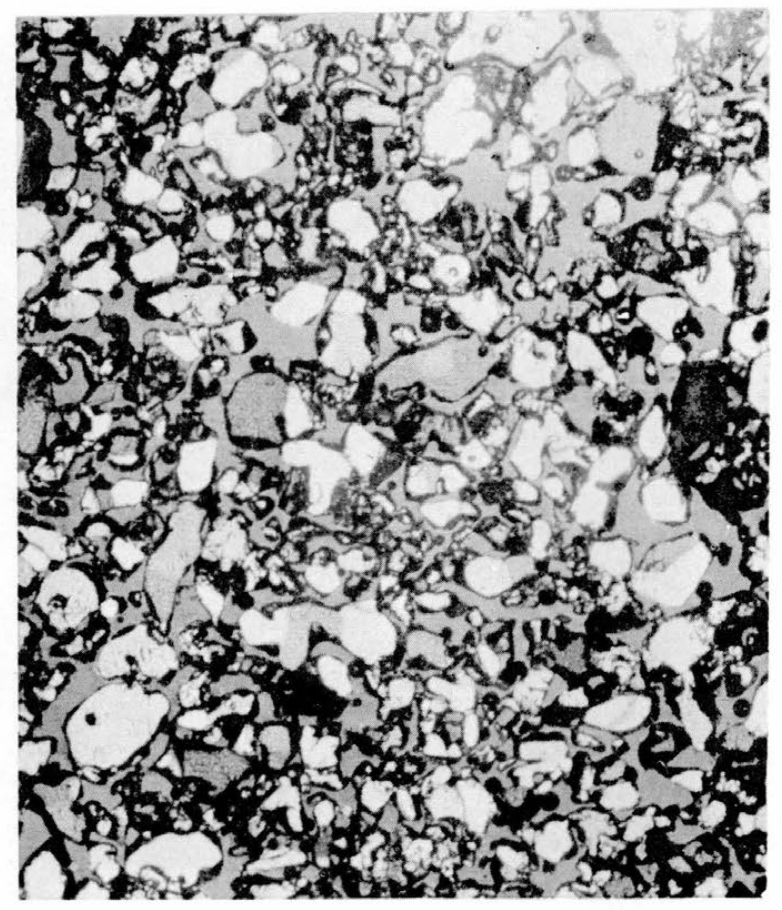

c) after $96 \mathrm{hr}$. Under crossed polaroids

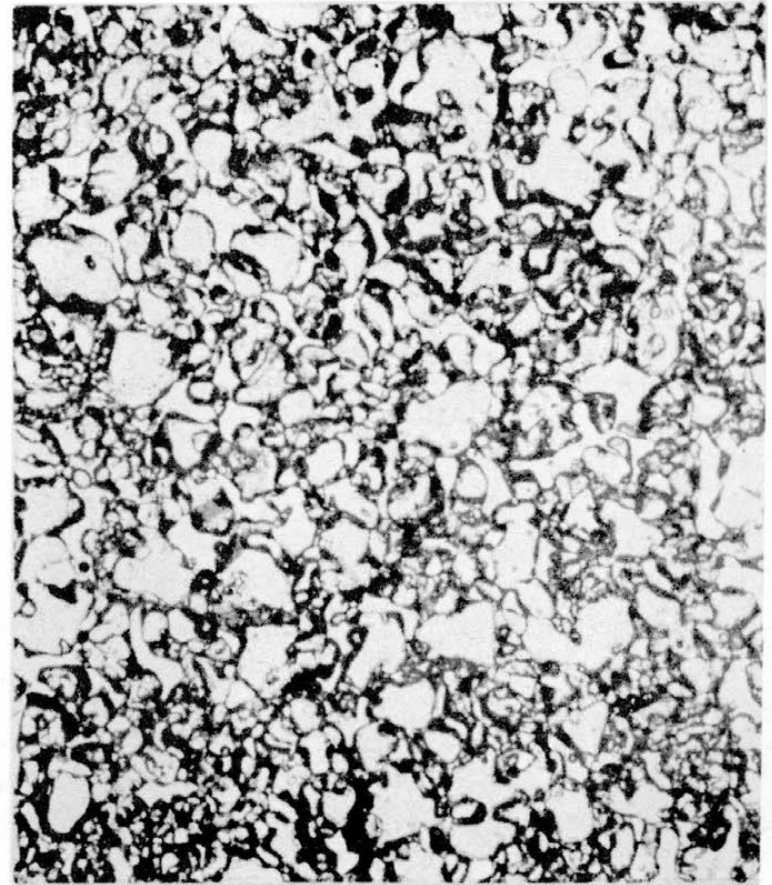

d) after $624 \mathrm{hr}$

Figure 9. Thin-section photographs of age-hardened structure in series B samples. 9X magnification. 


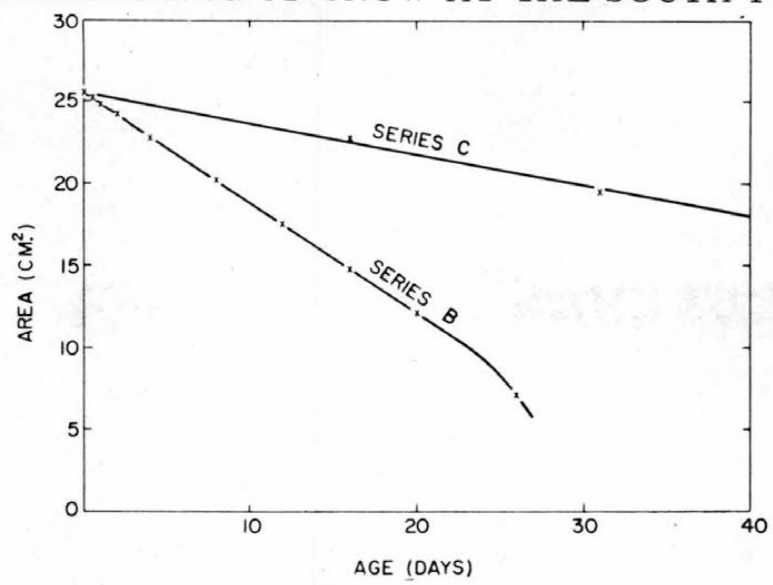

Figure 10. Cross-sectional area loss by sublimation of snow cylinders in series $B$ and series $C$.

Series C. This series was also aged at the ambient air temperature but the samples were placed in a ventilated box to eliminate the effects of solar radiation. It can be seen from' Figure 10 that the series C samples underwent much less sublimation than did the samples in series B. Results of compressive strength tests are given in Figure 11 and Table AIII and thin-section structures are shown in Figure 13.

Series D. These samples were aged for $384 \mathrm{hr}$ under approximately the same conditions as for series $C$, i. e. at ambient air temperatures and protected from solar radiation. Figure 12 gives the compressive strength values as a function of particle size; each data point represents the average of five tests, the results of which are given in Table AIV. The horizontal line drawn through each point indicates the range of grain sizes within a group of samples. Two samples from each group in series D were retained unbroken and deposited in the snow mine with samples from series A. These will be crushed after two years' aging to determine the effect of a constant low temperature on structure and subsequent strength. Thin-section photographs of the age-hardened snow structure after $384 \mathrm{hr}$ and at the end of 1 year are given in Figure 14.

Series E. During the winter of 1957, a snow mine was excavated to a depth of $27.5 \mathrm{~m}$ below the surface at the South Pole. The following year, M. Giovinetto (1960) systematically cored one wall of the snow mine to obtain samples for density and pollen analyses at different depths. Most of the cores were replaced in the original drill holes, and a large number of these cores were used for measuring the compressive strength of naturally compacted snow at depths from 7.5 to $27.5 \mathrm{~m}$ below the surface. Above $7.5 \mathrm{~m}$, Giovinetto's cores had not been replaced so fresh cores were cut to within $4.5 \mathrm{~m}$ of the surface with a standard $3-\mathrm{in} .(7.6-\mathrm{cm})$ coring auger. Because of the excessive accumulation near the portal, it was not possible to obtain undisturbed samples in the first $4 \mathrm{~m}$ in the mine. These shallow samples were taken from the $4-\mathrm{m}$ pit. Since the snow in the pit lacked the cohesion of the deeper deposits, the 3-in. coring auger could not be used and samples were obtained with standard SIPRE snow tubes. All samples were trimmed to $19.8-\mathrm{cm}$ length and crushed in unconfined compression at $-49 \mathrm{C}$. A $5000-1 \mathrm{~b}(2250-\mathrm{kg})$ proving ring was required to measure the crushing strengths of the high-density samples from near the bottom of the snow mine. A plot of the crushing strength versus density is shown in Figure 15. Actual test values are listed in Table AV. Some average values obtained by Butkovich (1956) at Site 2, Greenland, are included for comparison. Thin-section photographs in Figure 16 illustrate the changes in structure with increasing depth of burial in snow and firn at the South Pole.

\section{Discussion}

It can readily be shown that the process of age hardening is strongly dependent on temperature by comparing low temperature studies at the South Pole with results 


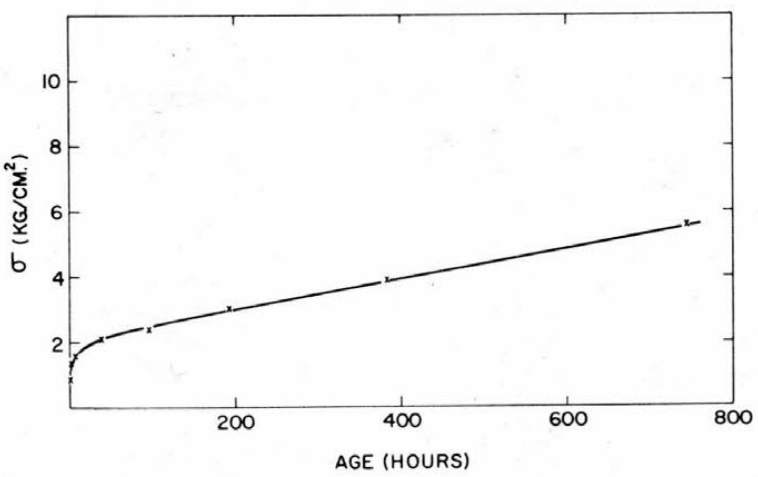

Figure 11. Unconfined compressive strengths of snow cylinders in series C. Each point represents the average of eight tests.

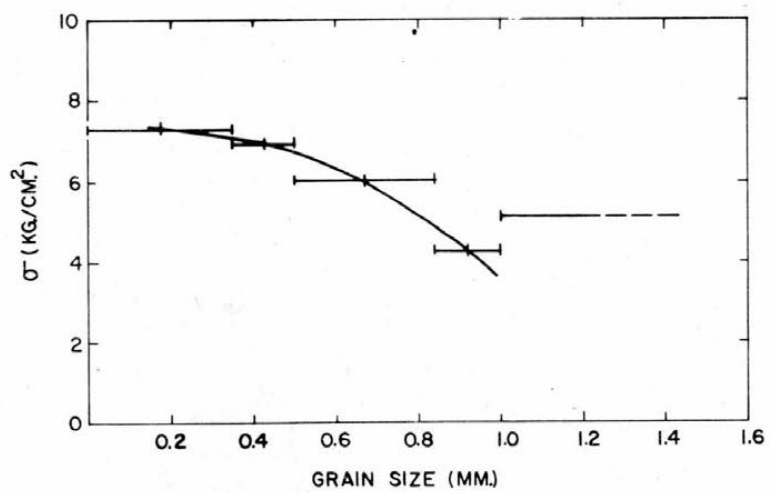

Figure 12. Compressive strength as a function of particle size for series D samples. All samples were aged for $384 \mathrm{hr}$. Each point represents the average of five tests. 


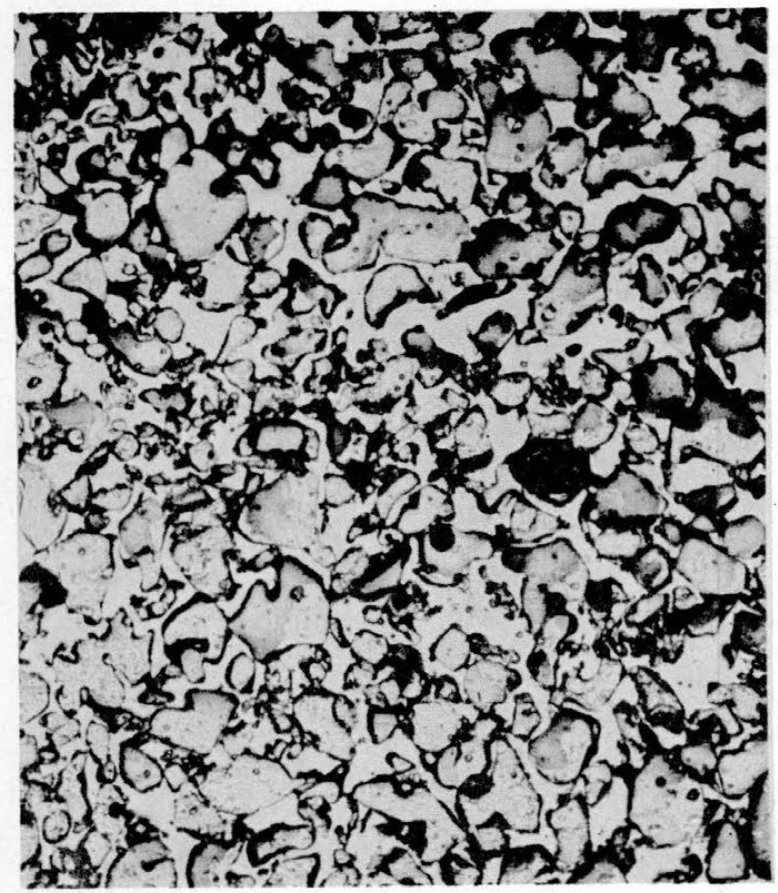

a) after $24 \mathrm{hr}$

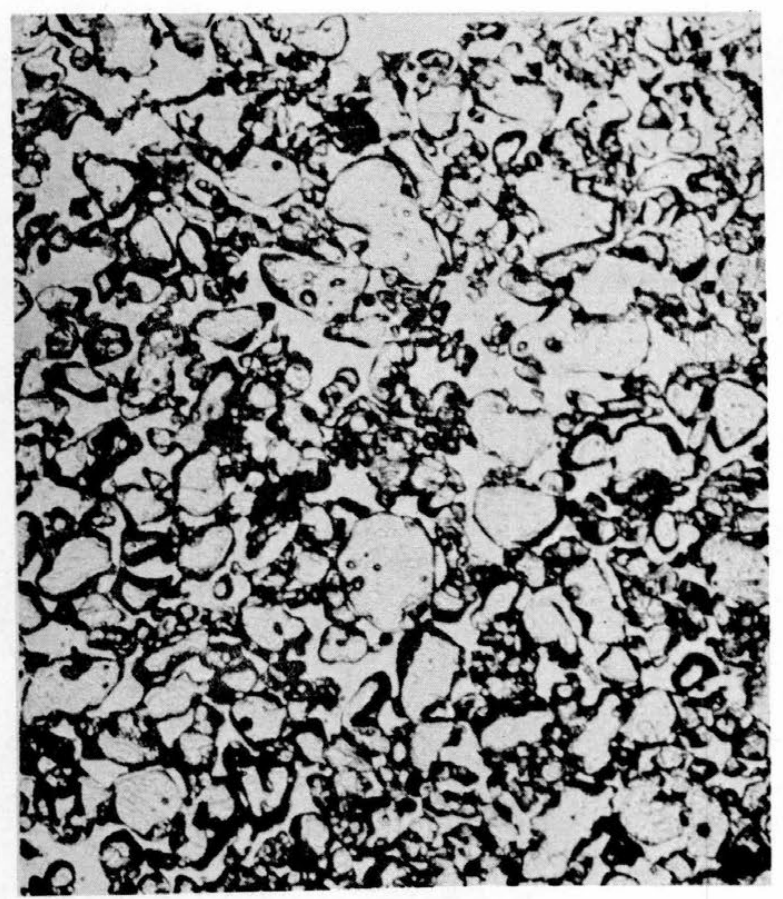

c) after $384 \mathrm{hr}$

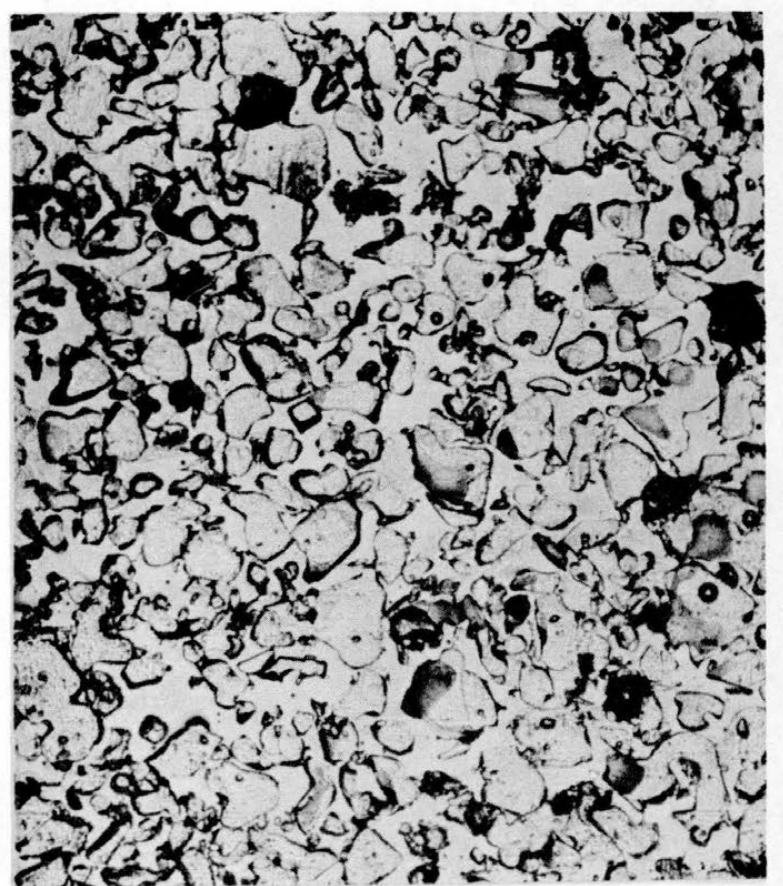

b) after $48 \mathrm{hr}$

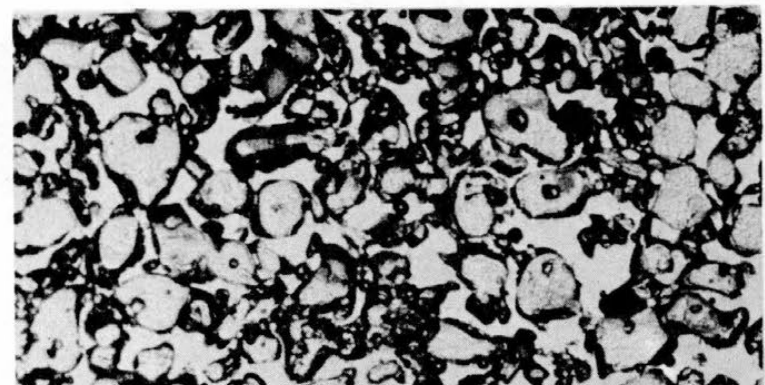

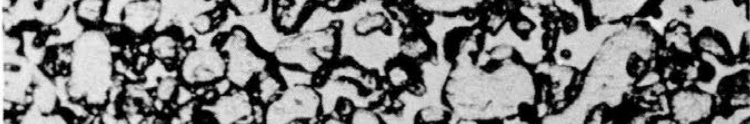

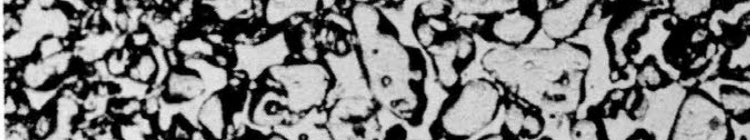

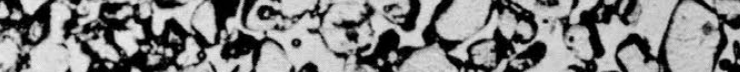

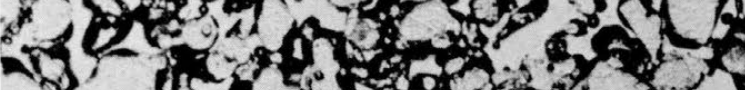

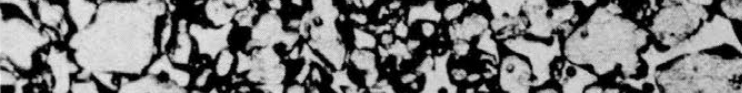
7i.

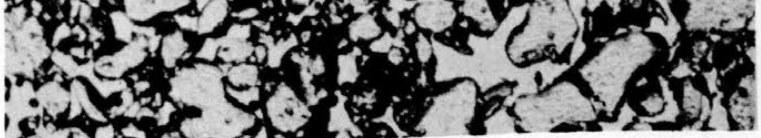

d) after $768 \mathrm{hr}$

Figure 13. Thin-section photographs of age-hardened structure in series C samples. 9X magnification. 
obtained by Jellinek (1957) on the age hardening of snow at -10C. Jellinek found that artificially compacted snow attained a near maximum strength of $10 \mathrm{~kg} / \mathrm{cm}^{2}$ after about $100 \mathrm{hr}$ at $-10 \mathrm{C}$. In the series $\mathrm{A}$ tests at $-49 \mathrm{C}$, the samples had acquired a strength of less than $0.8 \mathrm{~kg} / \mathrm{cm}^{2}$ after $100 \mathrm{hr}$, i.e. about $8 \%$ of the strength attained at $-10 \mathrm{C}$. After $768 \mathrm{hr}$ of aging the series A samples had acquired a strength of $1.25 \mathrm{~kg} / \mathrm{cm}^{2}$ increasing to $1.5 \mathrm{~kg} / \mathrm{cm}^{2}$ at $1500 \mathrm{hr}$ and becoming $1.8 \mathrm{~kg} / \mathrm{cm}^{2}$ after $3000 \mathrm{hr}$. Additional tests of the series A samples show that they are still gaining in strength at an approximately constant but very low rate (Fig. 5).

By comparison we find that the naturally compacted snow in series $E$ at the same density $\left(0.55 \mathrm{~g} / \mathrm{cm}^{3}\right)$ has a strength of about $20 \mathrm{~kg} / \mathrm{cm}^{2}$. Nakaya and $\cdot W$ aterhouse (personal communication) have been able to correlate an increase in Young's modulus with increasing strength in Greenland snow, and according to Nakaya (1962) the Young's modulus (and hence the strength) of disaggregated snow at Site 2, Greenland, exceeded that of naturally compacted snow after only l year's aging. Such a rate of age hardening does not occur at the low temperatures experienced at the South Pole. Results from series A show that it would take a very long time for artificially compacted snow of density $0.55 \mathrm{~g} / \mathrm{cm}^{3}$ at a temperature of $-49 \mathrm{C}$ even to approach the strength of naturally compacted snow of the same density. Furthermore, age hardening in naturally compacted and artificially compacted snow are not strictly comparable processes. It should be realized that naturally compacted snow of density $0.55 \mathrm{~g} / \mathrm{cm}^{3}(19-\mathrm{m}$ depth) at the South Pole has passed through a long history (more than $100 \mathrm{yr}$ ) of recrystallization and structural changes. These changes have occurred under conditions of very low temperature and slowly applied overburden pressure. On the other hand the series A samples were compacted very rapidly to a density of $0.55 \mathrm{~g} / \mathrm{cm}^{3}$ and then aged.

In series $\mathrm{C}$, aged at the ambient air temperature which averaged $-26 \mathrm{C}$ for the duration of the studies, the rate of age hardening was much higher than for series A. After $100 \mathrm{hr}$, the strength had exceeded $2.5 \mathrm{~kg} / \mathrm{cm}^{2}$. Thereafter, the rate of increase remained constant, reaching a strength of about $6.0 \mathrm{~kg} / \mathrm{cm}^{2}$ after $800 \mathrm{hr}$.

The samples in series B were also maintained at the ambient air temperature, but the rapid increase in strength can be attributed to exposure to solar radiation. After $100 \mathrm{hr}$, the strength had reached $6.0 \mathrm{~kg} / \mathrm{cm}^{2}$. With additional aging, the strength increased at a much reduced rate, reaching $8.0 \mathrm{~kg} / \mathrm{cm}^{2}$ after $600 \mathrm{hr}$.

Studies of the effect of particle size on the compressive strength of artificially compacted snow (series D) showed that the strength decreased appreciably with increase in grain size. It was observed however that the fine-grained particles were generally more angular than the coarser particles, so that the apparent correlation between strength and grain size may be in part a function of grain shape. In contrast to the present result, Jellinek (1957) found the strength of artificially compacted snow to increase with increasing grain size. Jellinek also noted that the coarse-grained samples required much more work of compaction to be compressed to a density of $0.55 \mathrm{~g} / \mathrm{cm}^{3}$ than did the finer-grained samples. He attributed the somewhat greater strength of coarsegrained samples to recrystallization and firmer bond formation in the more highly stressed grains of the coarse-grained samples. However, it is possible that many of the coarser grains (consisting in large part of crystal aggregates) were broken during compaction, causing a resultant overall reduction of grain size and changes in grain shape. It would seem that the shape of grains is just as important as their size in determining the number of contacts between grains, and hence the potential number of bonds and the ultimate strength of an artificially compacted aggregate. As already mentioned in the section on experimental methods, it proved possible to prepare samples of almost constant density $\left(0.554 \pm 0.005 \mathrm{~g} / \mathrm{cm}^{3}\right)$, equivalent to $39-40 \%$ porosity. Redetermination of densities just prior to testing revealed no significant changes, even after considerable aging. Thus, apart from the growth of bonds.in the grain contact areas, low-temperature age hardening results in negligible changes in the bulk structure of a moderately compacted aggregate.

The plot of crushing strength versus density for series E (Fig. 15) shows that strength increases very rapidly with density. Although there is a large variation in strength for the $4-\mathrm{m}$ pit samples, the strength of snow from the mine increases linearly at densities above $0.42 \mathrm{~g} / \mathrm{cm}^{3}$, except for one distinct break at a density of $0.55 \mathrm{~g} / \mathrm{cm}^{3}$. 


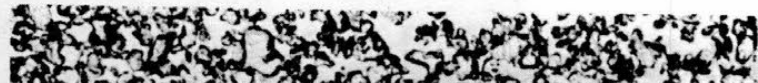
TS ${ }^{2}$.

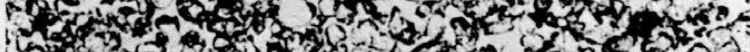

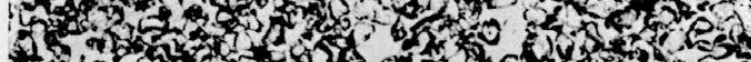

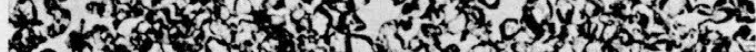

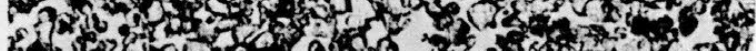

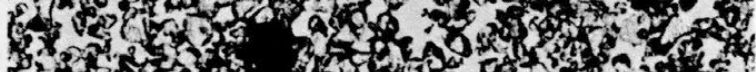
2.3.

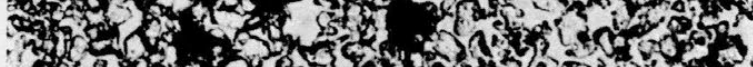

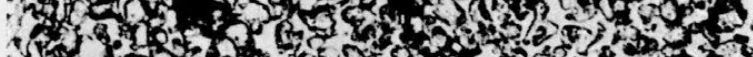

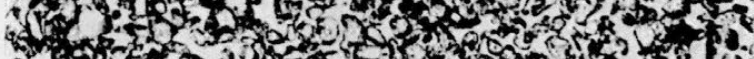

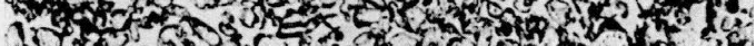

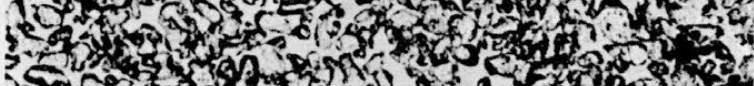
3.

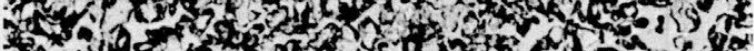
3. J 0 (n)

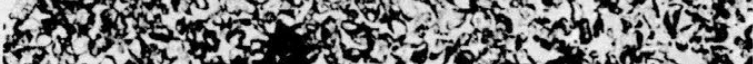

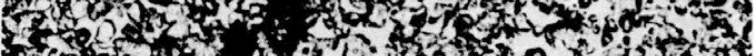

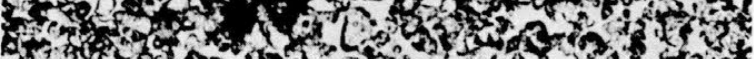

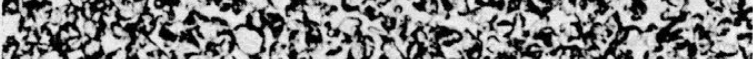

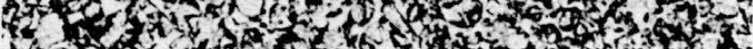

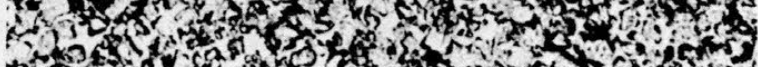

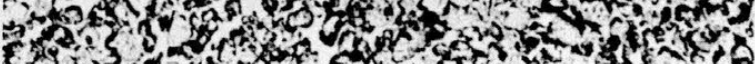

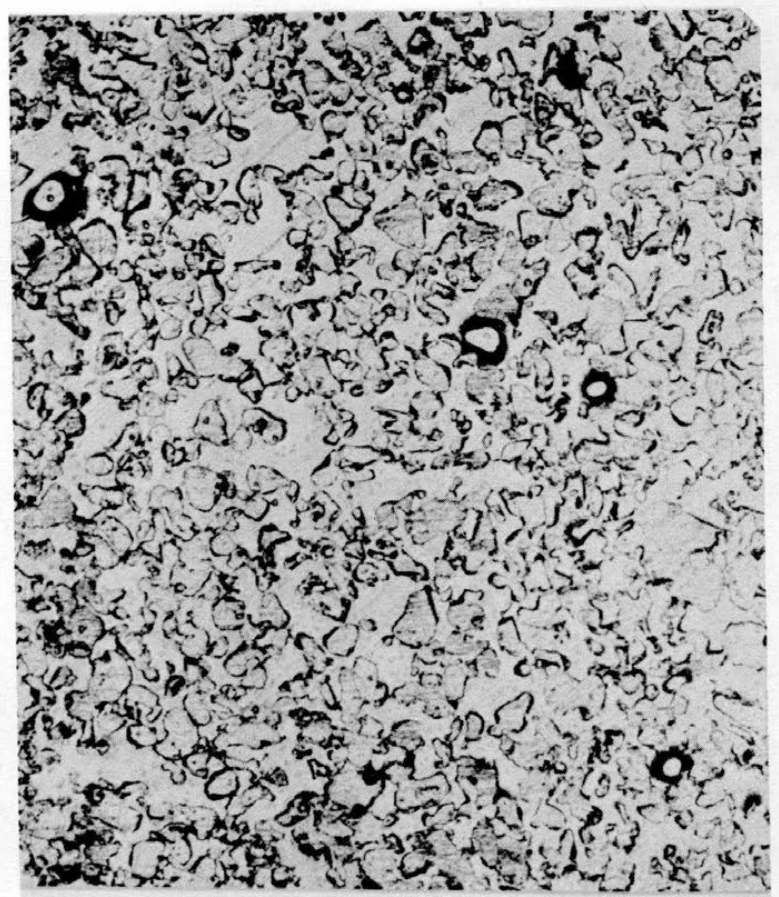

a) after $384 \mathrm{hr}$. Grain size $\leqq 0.34 \mathrm{~mm}$

b) after $384 \mathrm{hr}$. Grain size 0.35-0.50 mm
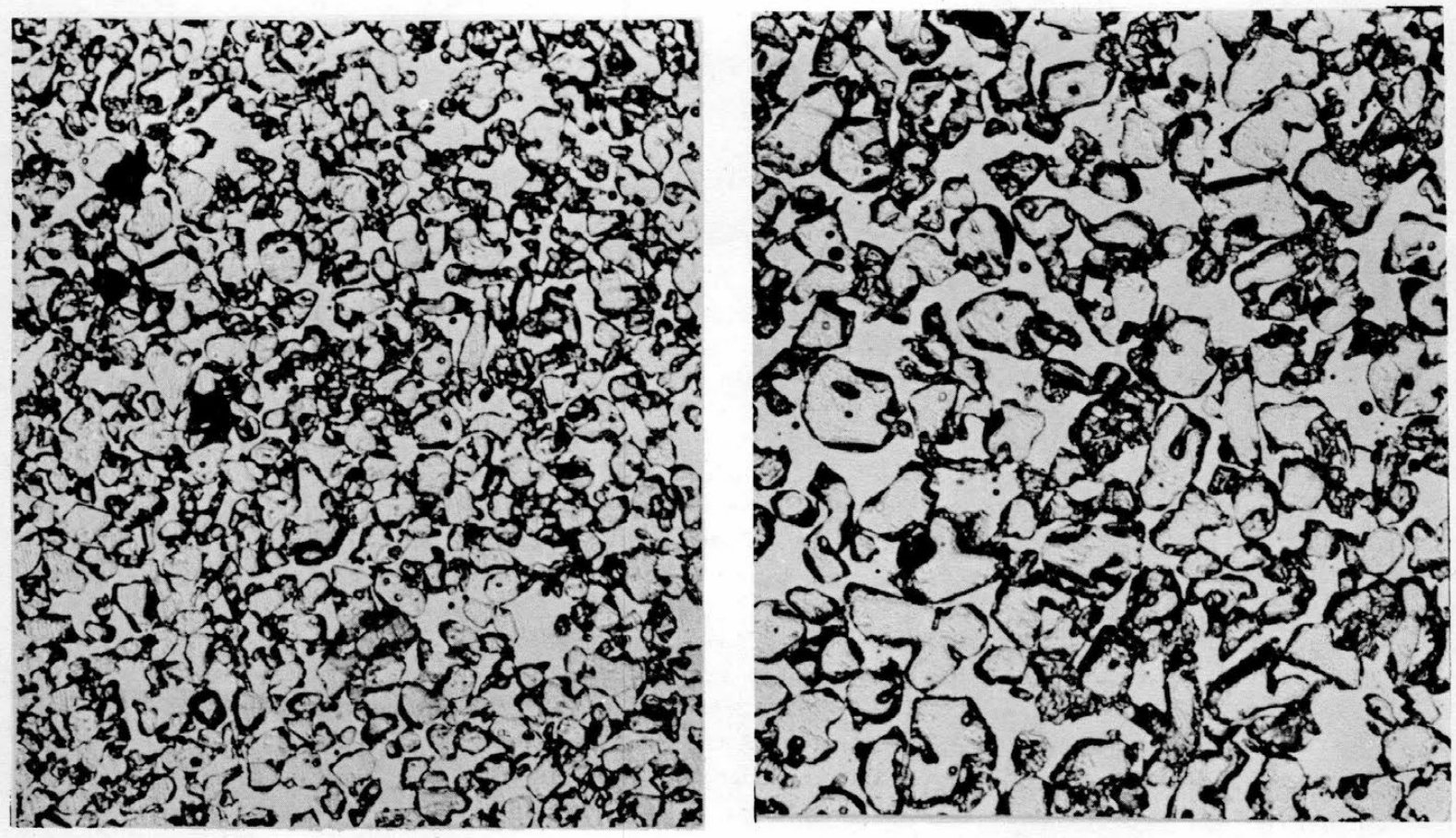

c) after $384 \mathrm{hr}$. Grain size 0.50-0.84 mm

d) after $384 \mathrm{hr}$. Grain size 0.84-1.00 mm

Figure 14. Thin-section photographs of age-hardened structure in series D samples. 9X magnification. 


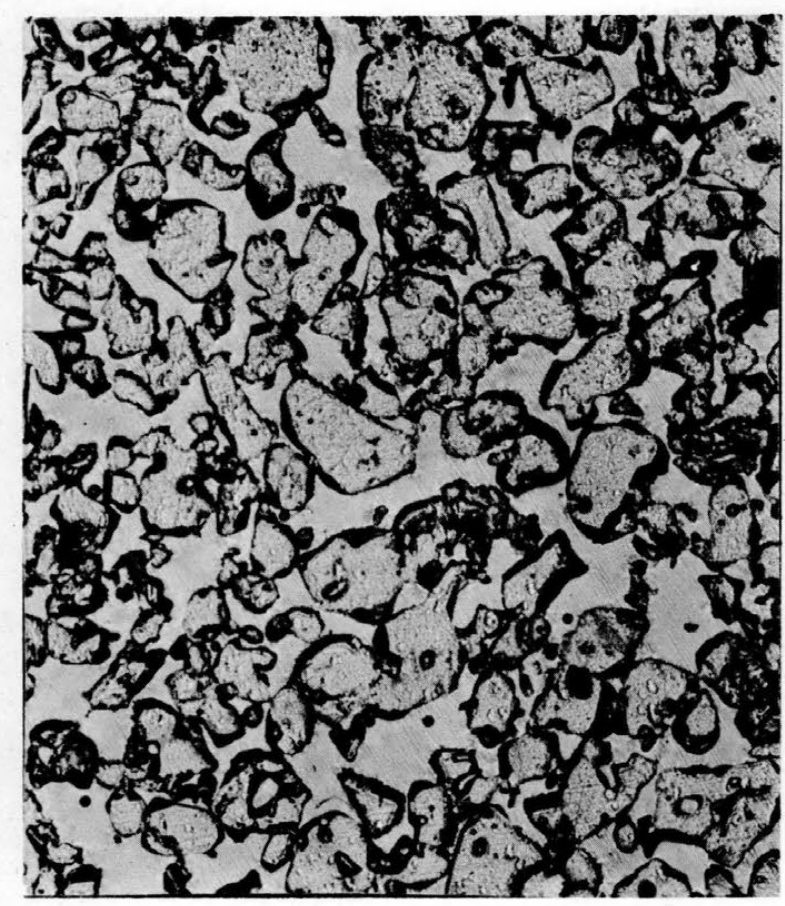

e) after $384 \mathrm{hr}$. Grain size $\stackrel{\geqq}{=} 1.00 \mathrm{~mm}$

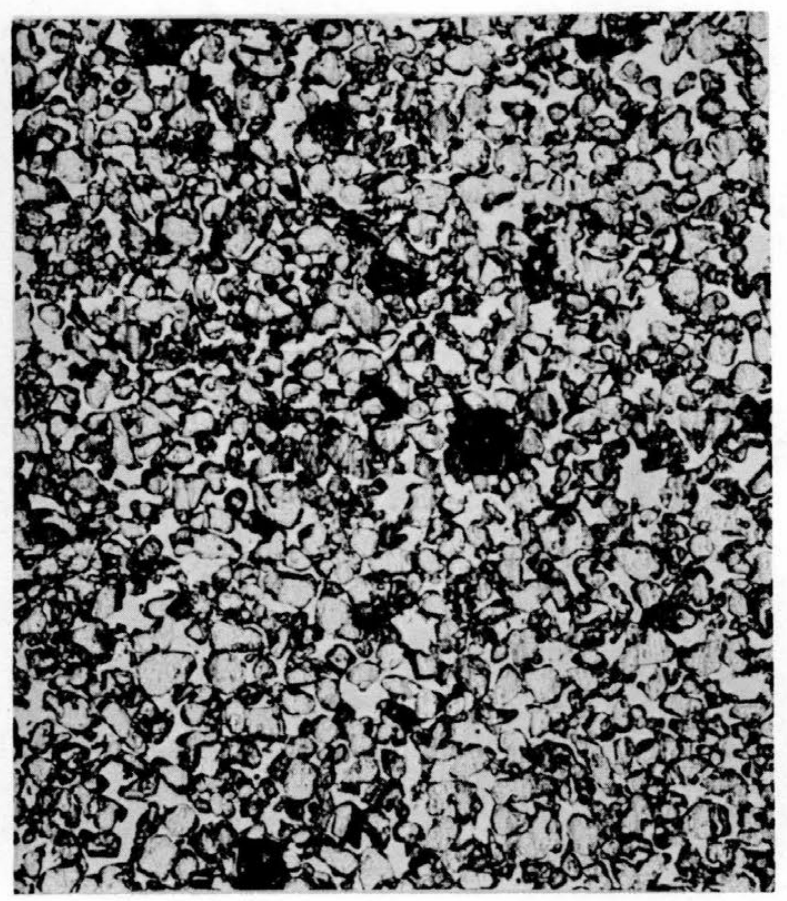

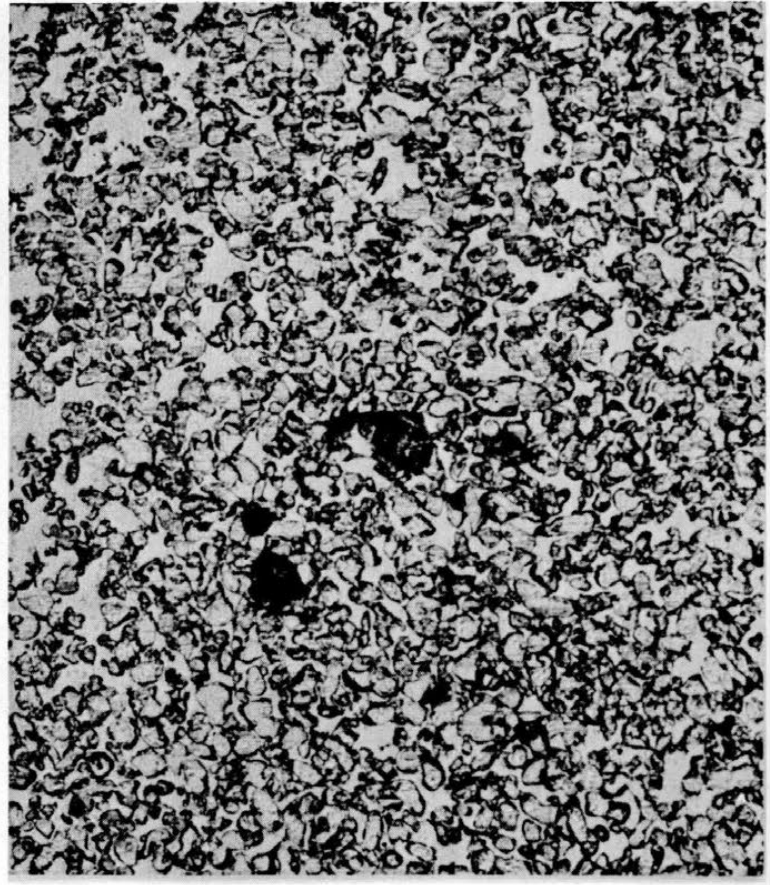

f) after 1 year. Grain size $\leqq 0.34 \mathrm{~mm}$

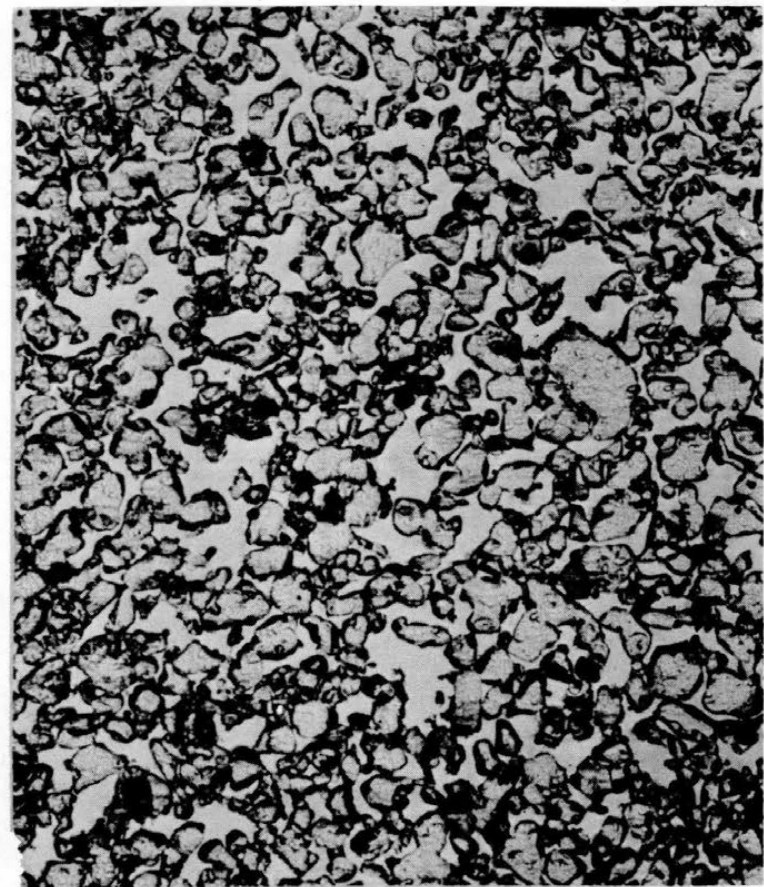
g) after 1 year. Grain size $0.35-0.50 \mathrm{~mm}$
h) after 1 year. Grain size 0.50-0.84 $\mathrm{mm}$

Figure 14. (Cont'd) Thin-section photographs of age-hardened structure in series D samples. 9X magnification. 


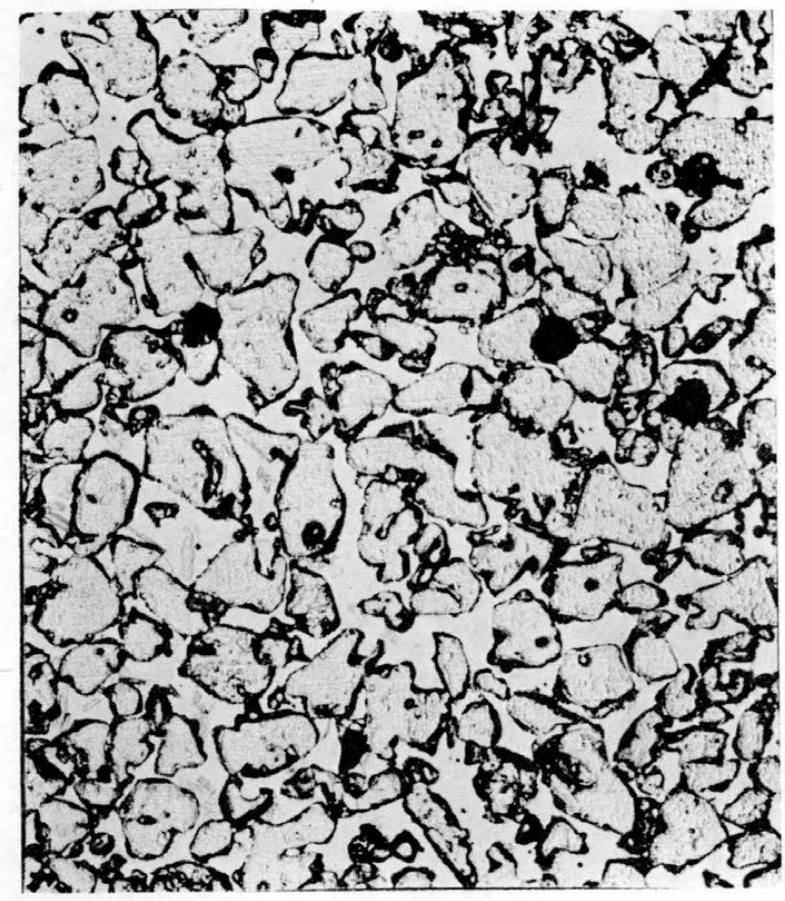

i) after 1 year. Grain size 0.84-1.00 mm

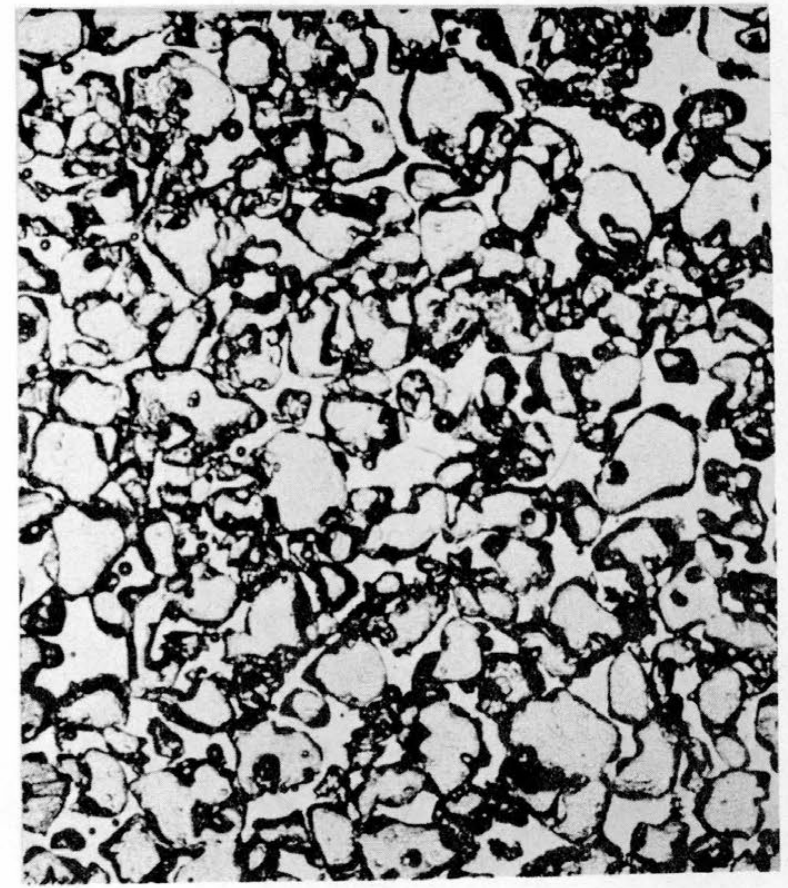

j) after 1 year. Grain size $\geqq 1.00 \mathrm{~mm}$

Figure 14. (Cont'd) Thin-section photographs of age-hardened structure in series D samples $9 X$ magnification.

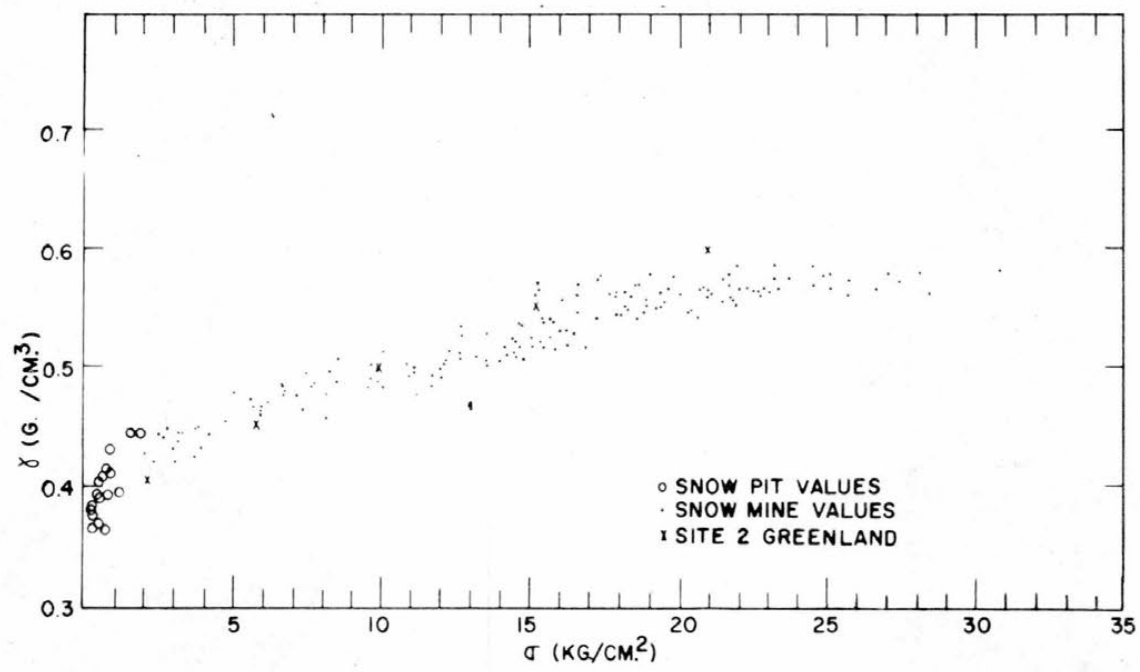

Figure 15. Strength $\sigma$ plotted against density $\gamma$ of naturally compacted snow at the South Pole. Each point represents the urconfined compressive strength of a single sample in series E. 


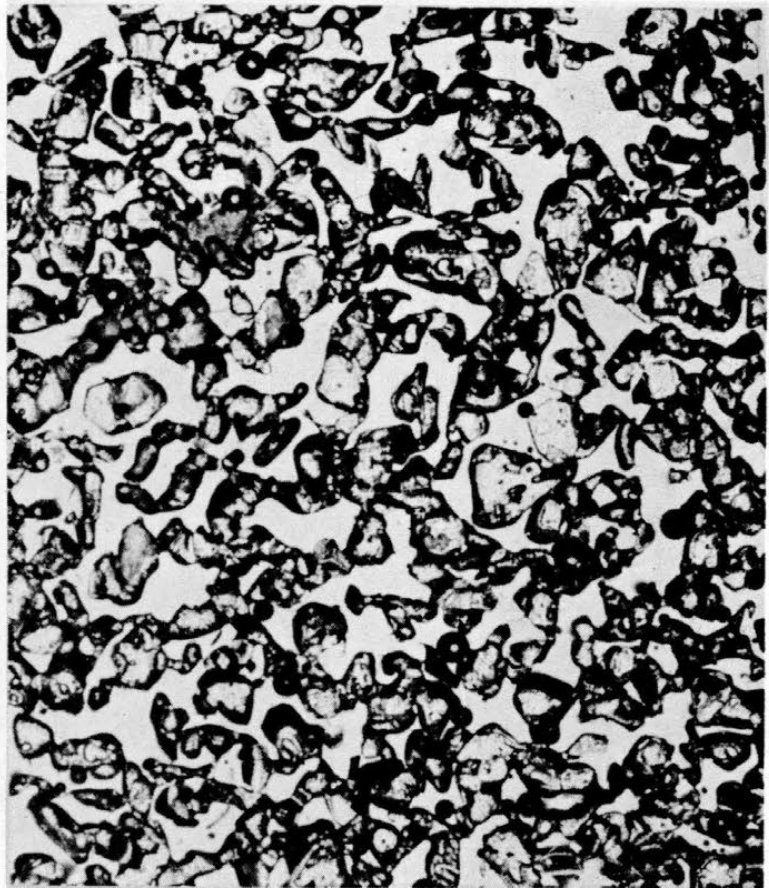

a) $0.6 \mathrm{~m}$ depth; density $0.37 \mathrm{~g} / \mathrm{cm}^{3}$

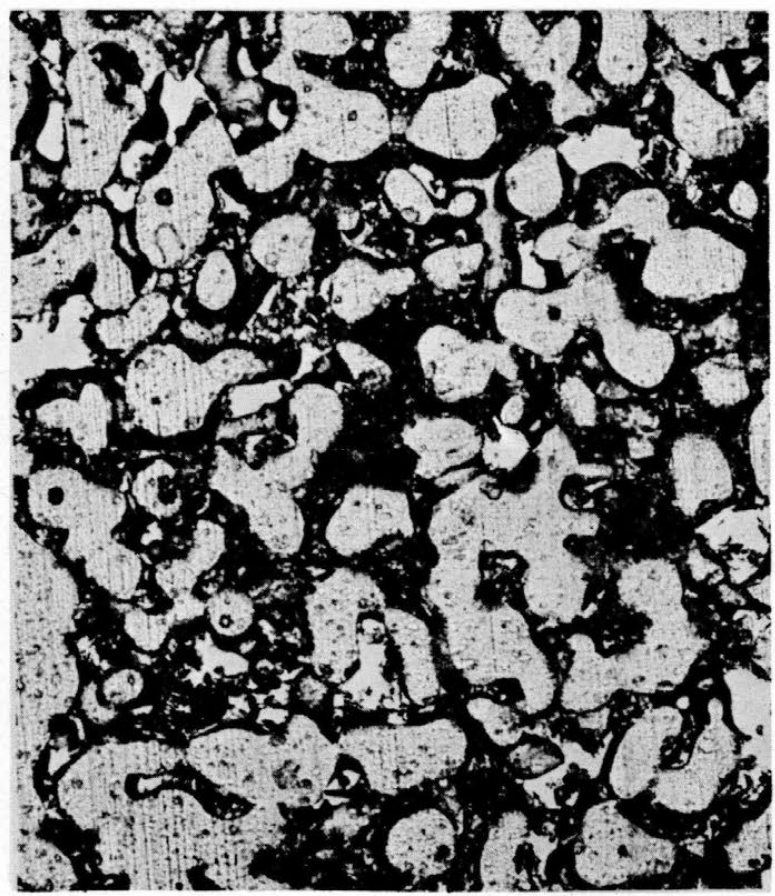

c) $20.0 \mathrm{~m}$ depth; density $0.55 \mathrm{~g} / \mathrm{cm}^{3}$

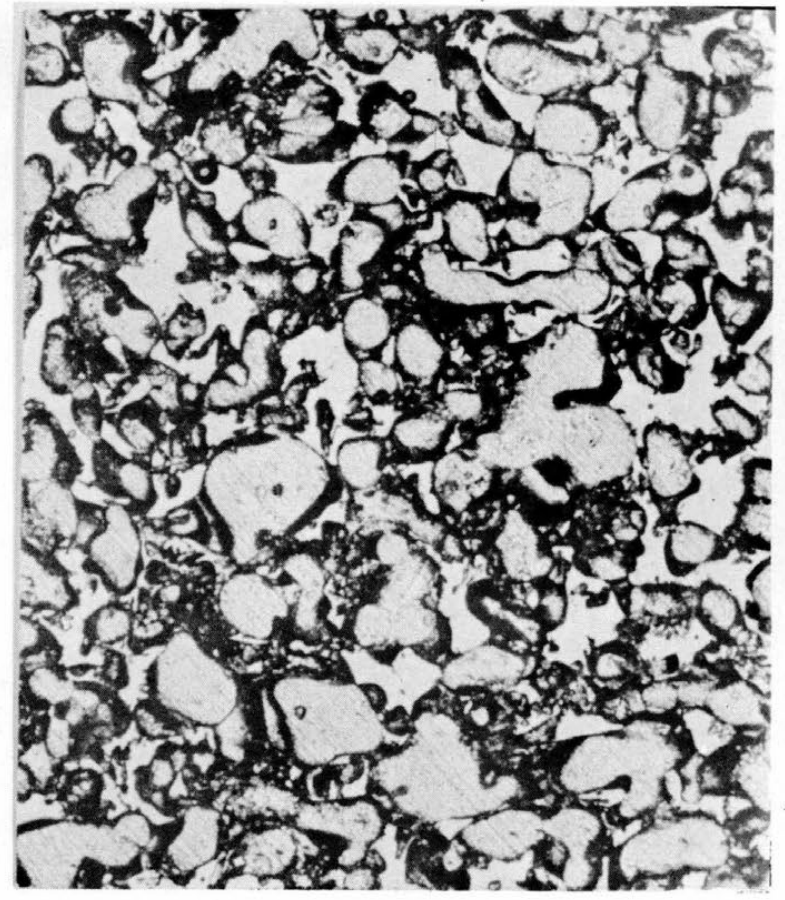

b) $6.0 \mathrm{~m}$ depth; density $0.45 \mathrm{~g} / \mathrm{cm}^{3}$

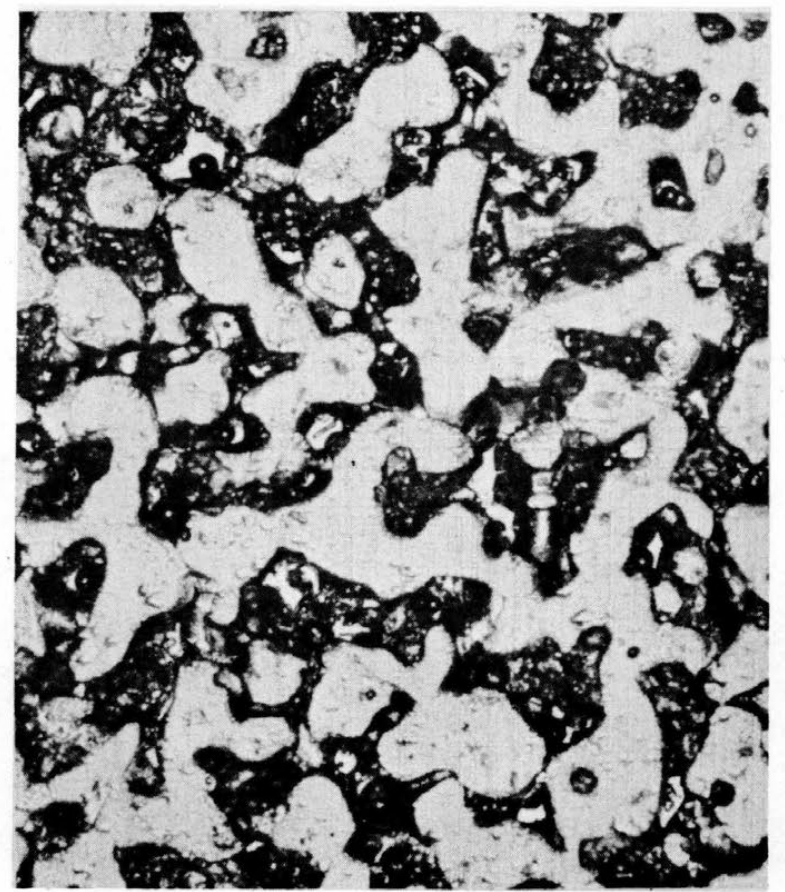

d) $48.0 \mathrm{~m}$ depth; density $0.65 \mathrm{~g} / \mathrm{cm}^{3}$

Figure 16. Thin-section photographs of the grain structure of naturally compacted snow (series E) at the South Pole. The dark areas in (c) and (d) are pore spaces filled with partially melted aniline. 9X magnification. 
Conclusions

Age hardening at the South Pole at low temperatures is very slow. Exposing samples to solar radiation greatly accelerated the process. However, an artificially compacted snow cover would not gain strength as rapidly as the series B snow cylinders because of the difference in the amount of direct solar radiation received. Because of the low angle of incidence of the sun's radiation at the South Pole (less than $23^{\circ}$ during December and January) the snow surface would absorb considerably less solar energy than the test samples which were set up vertically on the surface. In the particular case of snow processed for engineering purposes a thin layer of artificially compacted snow would probably not gain in strength at a rate much faster than that found for the series C samples (protected from solar radiation). A thicker layer would not strengthen uniformly because of the fairly rapid decrease in temperatures with depth in the layer.

Jellinek (1957) was able to satisfactorily fit his -10C age-hardening curves with the equation

$$
\frac{\mathrm{S}_{\mathrm{f}}-\mathrm{S}_{\mathrm{t}}}{\mathrm{S}_{\mathrm{f}}-\mathrm{S}_{0}}=\mathrm{e}^{-\mathrm{kt}}
$$

where $S_{0}$ and $S_{f}$ are the initial and final compressive strengths respectively, $S_{t}$ is the compressive strength at the time $\underline{\mathrm{t}}$, and $\underline{\mathrm{k}}$ is a rate constant. An attempt has been made to apply the same equation to the results from the South Pole and also to data obtained by Butkovich (1962) and Wuori (1962) with artificially processed snow. The constants used to construct the curves in Figure 17 are listed in Table I. It should be noted, however, that Jellinek was able to estimate $S_{f}$ very closely because his samples had attained almost maximum strength after $100 \mathrm{hr}$. This was not the case at the South Pole, where the results showed that samples were still gaining in strength at the end of the tests - approximately $700 \mathrm{hr}$ for the field tests. To facilitate the calculations, the value assigned to $S_{f}$ was that strength attained after approximately $700 \mathrm{hr}$ aging. It can be seen in Figure 17 that all the calculated curves with the exception of the series A tests at $-49 \mathrm{C}$ deviate considerably from the experimentally determined values, especially in the early stages of age hardening. The non-uniform conditions under which some of the tests were conducted may be partly responsible. For instance, the series B and series C samples at the South Pole were aged at the ambient temperature, which fluctuated from day to day (Fig. 7). Similarly, the processed snow used by Butkovich and Wuori had also been subjected to natural variations in solar radiation and temperature. The very significant effect of solar radiation on the age-hardening process can be readily seen in the $-26 \mathrm{C}$ tests at the South Pole. However, it also appears that our estimates of $S_{f}$ were too low. Longterm testing of the series A samples has shown that the average strength has increased almost linearly from $1.2 \mathrm{~kg} / \mathrm{cm}^{2}\left(\mathrm{~S}_{\mathrm{f}}\right.$ at $\left.700 \mathrm{hr}\right)$ to nearly $3.0 \mathrm{~kg} / \mathrm{cm}^{2}$ after 1 year's aging. A constant rate of increase was also noted in the series $C$ samples after the first $100 \mathrm{hr}$ of aging, and this would suggest that, at least for low temperature tests, the age-hardening process cannot be expressed entirely satisfactorily in terms of Jellinek's equation. At least on the basis of the present analysis, it is rather difficult to find a direct relationship between the rate constant $\mathrm{k}$ and temperature. Of immediate interest would be further laboratory tests with the same type of snow to determine strength as a function of temperature. If the results of such tests can be accommodated in the first-order reaction equation suggested by Jellinek then it would be possible to derive an energy of activation for age hardening in snow.

The compressive strength was found to increase with decreasing particle size and with increasing angularity of the particles. The fact that fine-grained samples could be compacted to the test density of $0.55 \mathrm{~g} / \mathrm{cm}^{3}$ much more readily than coarsegrained snow clearly reflects the influence of particle shape and size distribution on the packing of particles in the compacted aggregate. The effects of these variables and also of variable degrees of compaction on the age-hardening properties of snow warrant further study. Presently available results suggest that optimum strengthening would be obtained with a fine-grained but poorly sorted aggregate composed of angular particles. In nature these conditions are perhaps most closely approached in certain windcompacted layers-fine-grained wind slabs. 
Table I. Parameters used to fit data.

$\begin{array}{ccccc}\mathrm{T} & \begin{array}{c}\mathrm{S}_{0} \\ \mathrm{~kg} / \mathrm{cm}^{2}\end{array} & \begin{array}{c}\mathrm{S}_{\mathrm{f}} \\ \mathrm{kg} / \mathrm{cm}^{2}\end{array} & \begin{array}{c}\mathrm{k} \\ \mathrm{hr} \times 10^{-3}\end{array} & \begin{array}{c}\text { Density } \\ \mathrm{g} / \mathrm{cm}^{3}\end{array} \\ -7 & 3.63 & 11.25 & 12.3 & 0.49 \\ -10 & 1.50 & 11.00 & 17.73 & 0.55 \\ -20 & 0.35 & 10.35 & 5.52 & 0.50 \\ -26 & 0.60 & \mathbf{8 . 1} & 9.83 & 0.55 \\ -26 & 0.70 & 5.2 & 3.81 & 0.55 \\ -49 & 0.02 & 1.2 & 5.66 & 0.55\end{array}$

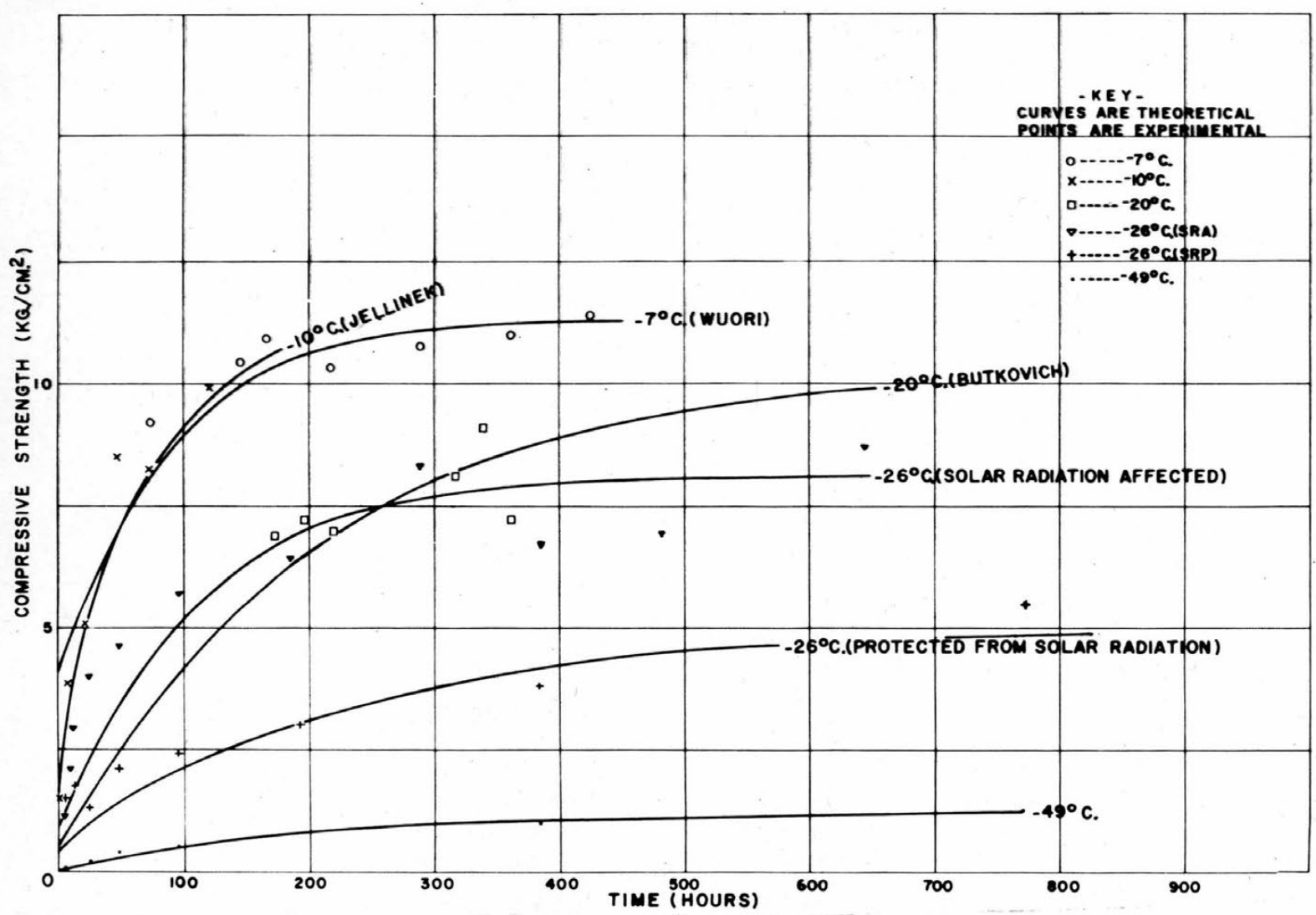

Figure 17. Age-hardening curves, calculated from the equation

$$
\frac{\mathrm{S}_{\mathrm{f}}-\mathrm{S}_{\mathrm{t}}}{\mathrm{S}_{\mathrm{f}}-\mathrm{S}_{0}}=\mathrm{e}^{-\mathrm{kt}}
$$

where $S_{f}$ and $S_{0}$ are the final and initial compressive strengths, $\mathrm{S}_{\mathrm{t}}$ is the compressive strength at time $\underline{\mathrm{t}}$, and $\underline{\mathrm{k}}$ is a rate constant. 
Naturally-compacted snow acquires considerable strength at depth. Near-surface snows (density less than $0.42 \mathrm{~g} / \mathrm{cm}^{3}$ ) possess rather low strength. The rate of increase of strength with density is essentially linear for densities between 0.42 and $0.55 \mathrm{~g} / \mathrm{cm}^{3}$. Above $0.55 \mathrm{~g} / \mathrm{cm}^{3}$ the strength appears to increase at an even greater rate.

Thin-section studies show that age hardening can be correlated with the formation and growth of bonds between grains. This occurs more rapidly at higher temperatures. and the whole process is essentially one of sintering. The relatively rapid initial strengthening in an artificially compacted snow sample can be attributed to the widespread formation of bonds at grain contacts. Subsequent age hardening at a diminishing rate probably reflects the continued growth of these early-formed intergranular bridges, plus growth of some new bonds. The process is obviously retarded at lower temperatures, as evidenced by the tendency for the samples at $-49 \mathrm{C}$ to crumble rather than fracture in unconfined compression even after considerable aging. In naturally compacted snow at the South Pole, the process is facilitated by diffusion, sublimation, and recrystallization under conditions of slowly increasing overburden pressure.

Since this work was performed at the South Pole a new undersnow camp has been successfully constructed at Byrd Station. However, in view of the low strength found in artificially compacted snow and in naturally compacted snow near the surface at the South Pole, the current "cut-and-cover" method of undersnow construction may not prove the most practical means of rebuilding the South Pole Station. Other methods are now being considered (Mellor, unpublished; Ramseier, unpublished).

\section{REFERENCES}

Bender, J. A. (1957) Testing of a compacted snow runway, Proceedings of the American Society of Civil Engineers, Journal of the Air Transport Division, vol. 83, no. 1, p. 1324-1-1324-20.

Butkovich, T. R. (1956) Strength studies of high-density snow, U. S. Army Snow, Ice and Permafrost Research Establishment (USA SIPRE) Research Report. 18.

(1962) Studies of the age hardening of processed snow, U. S. Army Cold Regions Research and Engineering Laboratory (USA CRREL) Research Report 99.

Fuchs, A. (1959) Some structural properties of Greenland snow, USA SIPRE Research Report $4 \overline{2}$.

(1960) Structure of age-hardening disaggregated Peter snow, USA SIPRE Research Report 53.

Giovinetto, M. B. (1960) Glaciology report for 1958, South Pole station, Ohio State University Research Foundation, Report 825-2, Part IV.

Jellinek, H. H. G. (1957) Compressive strength properties of snow, USA SIPRE Research Report 34.

Kingery, W. D. (1960) Regelation, surface diffusion, and ice sintering, Journal of Applied Physics, vol. 31, no. 5, p. 833-38.

Kinosita, S. and Wakahama, G. (1960) Thin sections of deposited snow made by use of aniline, Contributions from the Institute of Low Temperature Science, Ser. A, no. 15, p. 35-45.

Koch, J. P. and Wegener, A. (1930) Wissenschaftliche Ergebnisse der Danischen Expedition nach Dronning Louises-Land und quer uber das Inlandeis von Nordgronland, 1912-13, Meddelelser om Gronland, Bd. 75.

Kuroiwa, D. (1961) A study of ice sintering, Tellus, vol. 13, no. 2, p. 252-59.

Mellor, M. (Unpublished) Informal comments on South Pole construction, Report, USA CRREL, 1962. 


\section{REFERENCES (Cont'd)}

Nakaya, U. (1962) Elastic properties of processed snow with reference to its internal structure, USA CRREL Reseach Report 82.

Ramseier, R. O. (1962) Site data for construction planning $\rightarrow$ South Pole, Special Report to National Science Foundation, Washington, D. C.

Wuori, A. (1963) Snow stabilization for roads and runways, USA CRREL Technical Report 83. 


\section{APPENDIX A}

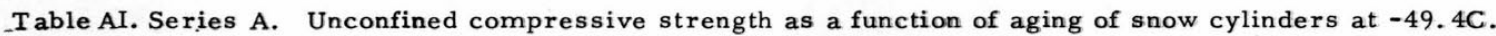

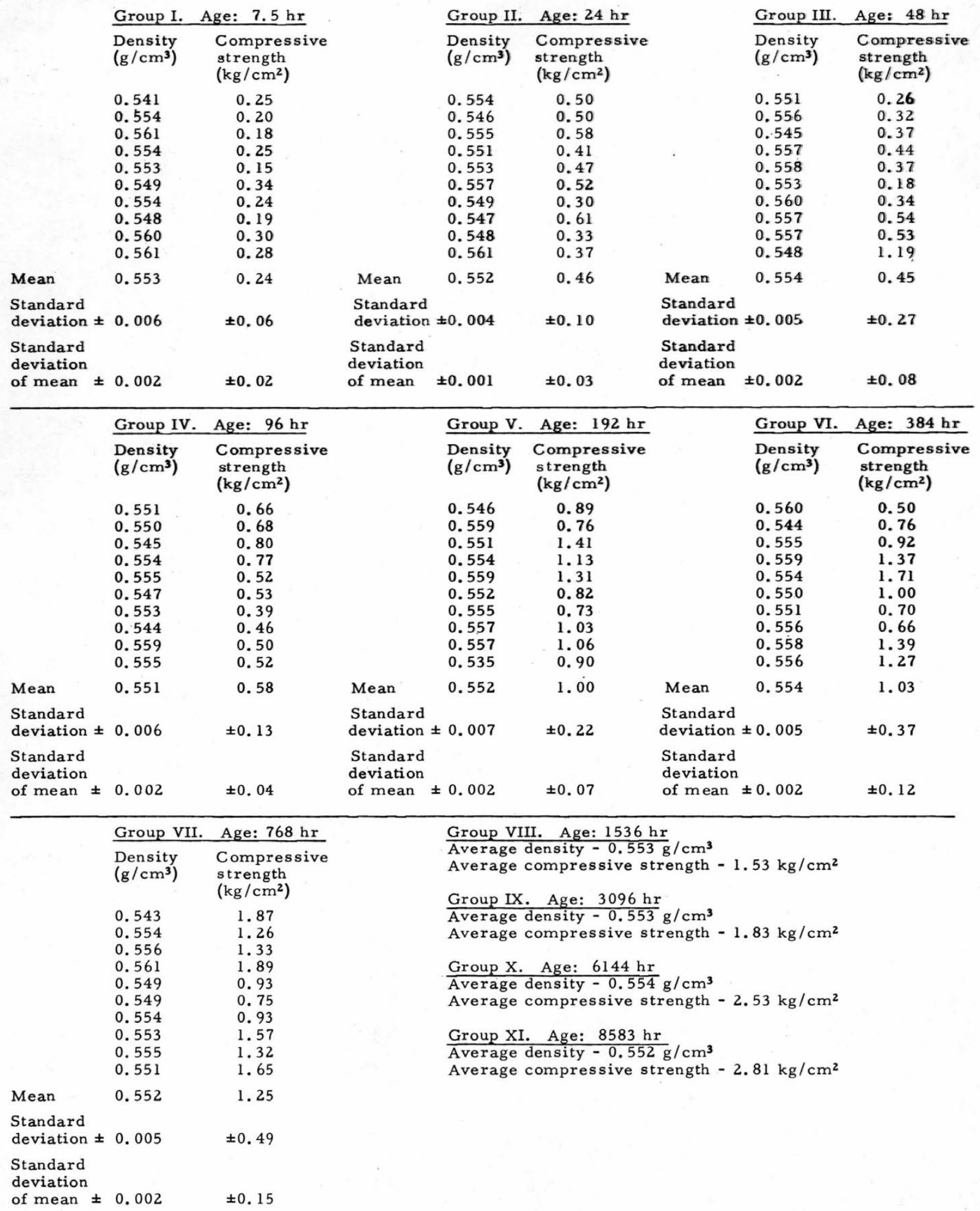


Table AII. Series B. Unconfined compressive strength as a function of aging of snow cylinders at ambient temperatures exposed to solar radiation.

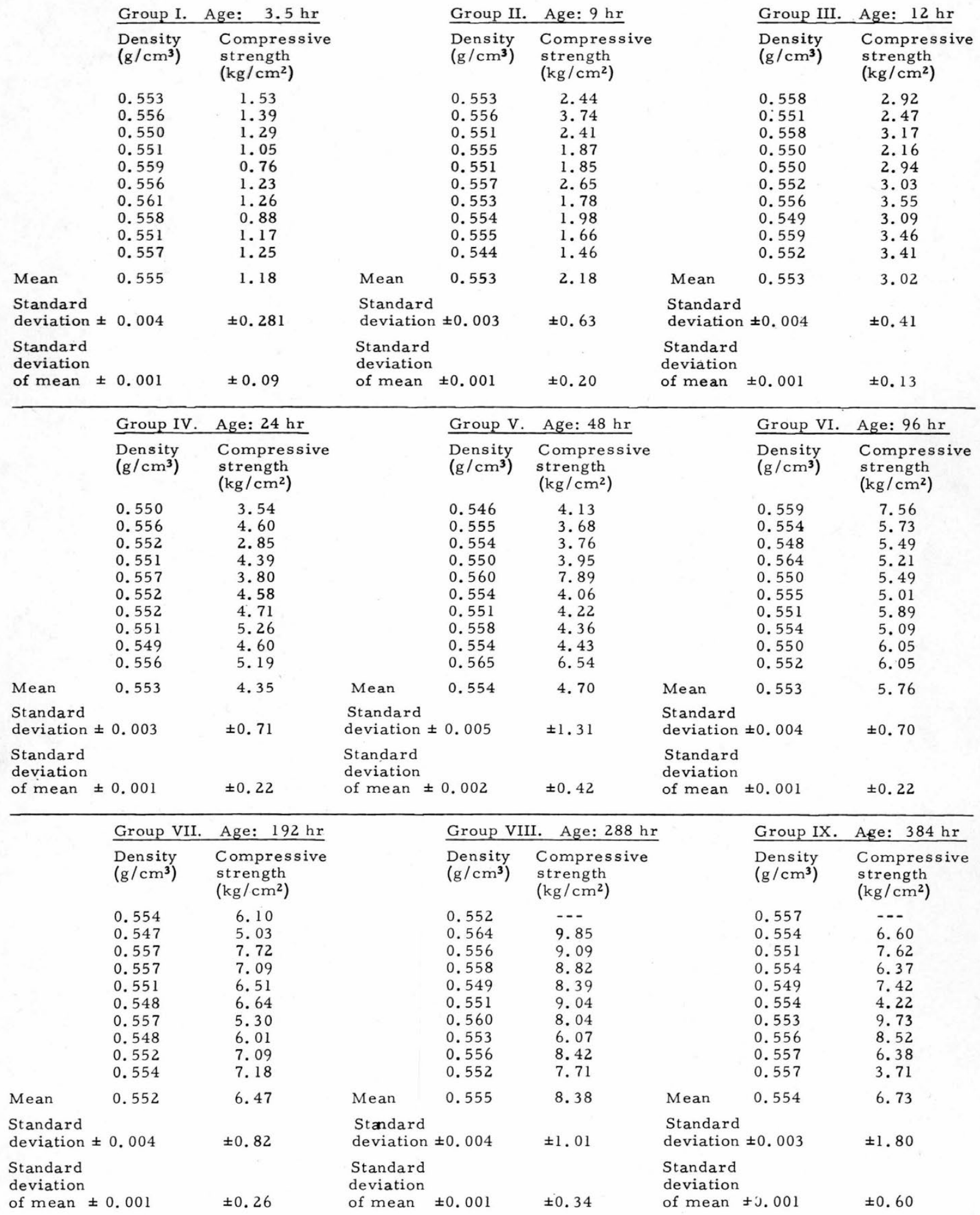


Table AII. (Cont'd) Series B. Unconfined compressive strength as a function of aging of snow cylinders at ambient temperatures exposed to solar radiation.

Group X. Age: $480 \mathrm{hr}$

$\begin{array}{ll}\text { Density } & \begin{array}{l}\text { Compressive } \\ \text { strength }\end{array}\end{array}$

$\left(\mathrm{kg} / \mathrm{cm}^{2}\right)$

0.552

0.550

0.552

0.556

0.557

0.551

0.557

0.551

0.560

0.546

Mean

0.553

Standard

deviation \pm 0.004

Standard

deviation

of mean \pm 0.001
7. 12

6. 94

$-\cdot-$

$--$

6.16

3.48

9.45

7. 73

7. 73

6.94

$\pm 1.70$

$\pm 0.64$
Group XI. Age: $624 \mathrm{hr}$

Density Compressive

$\left(\mathrm{g} / \mathrm{cm}^{3}\right) \quad$ strength

$\left(\mathrm{kg} / \mathrm{cm}^{2}\right)$

0.554

7. 05

$0.553 \quad 9.73$

$0.554 \quad 7.71$

0.556

0.551

0.556

0.556

0.552

0.553

0.560

$---$

9. 04

8. 75

8. 04

10.37

8.49

10.11

Mean

0.554

8.81

Standard

deviation $\pm 0.002 \quad \pm 1.06$

Standard

deviation

of mean \pm 0.001

$\pm 0.35$ 
Table AIII. Series C. Unconfined compressive strength as a function of aging of snow cylinders at ambient air temperature protected from solar radiation.

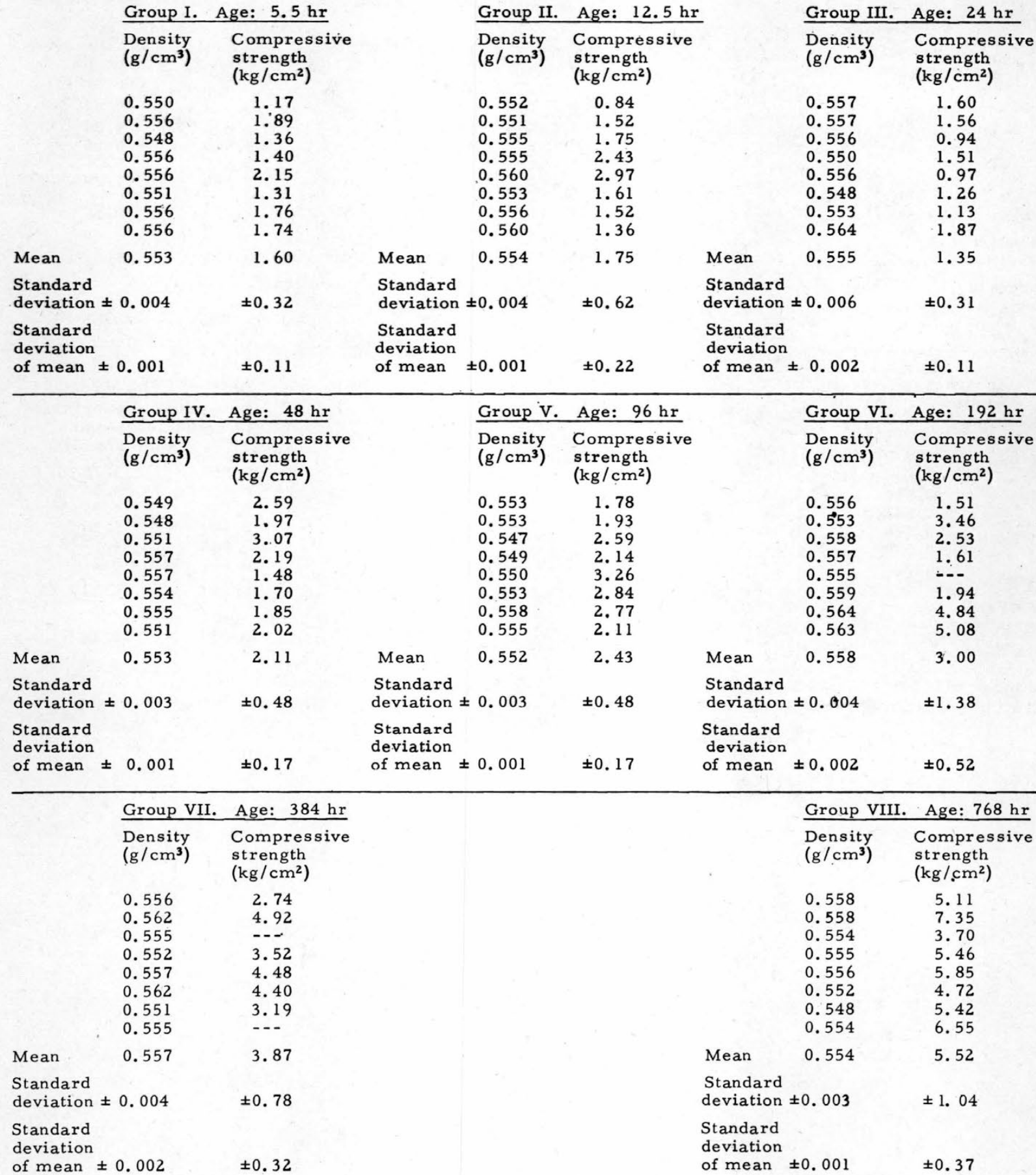


Table AIV. Series D. Unconfined compressive strength as a function of snow particle size of snow cylinders at ambient air temperature protected from solar radiation.

\begin{tabular}{|c|c|c|c|c|c|c|c|c|}
\hline & \multicolumn{2}{|c|}{$\begin{array}{l}\text { Grain size } 0-.35 \mathrm{~mm} \\
\text { Age: } 384 \mathrm{hr}\end{array}$} & \multicolumn{4}{|c|}{$\begin{array}{l}\text { Grain size } .35-.50 \mathrm{~mm} \\
\text { Age: } 384 \mathrm{hr}\end{array}$} & \multicolumn{2}{|c|}{$\begin{array}{l}\text { Grain size . } 50-.84 \mathrm{~mm} \\
\text { Age: } 384 \mathrm{hr}\end{array}$} \\
\hline & $\begin{array}{l}\text { Density } \\
\left(\mathrm{kg} / \mathrm{cm}^{3}\right)\end{array}$ & $\begin{array}{l}\text { Compressive } \\
\text { strength } \\
\left(\mathrm{kg} / \mathrm{cm}^{2}\right)\end{array}$ & & $\begin{array}{l}\text { Density } \\
\left(\mathrm{g} / \mathrm{cm}^{3}\right)\end{array}$ & $\begin{array}{l}\text { Compressive } \\
\text { strength } \\
\left(\mathrm{kg} / \mathrm{cm}^{2}\right)\end{array}$ & & $\begin{array}{l}\text { Density } \\
\left(\mathrm{g} / \mathrm{cm}^{3}\right)\end{array}$ & $\begin{array}{l}\text { Compressive } \\
\text { strength } \\
\left(\mathrm{kg} / \mathrm{cm}^{2}\right)\end{array}$ \\
\hline & $\begin{array}{l}0.576 \\
0.556 \\
0.563 \\
0.533 \\
0.572\end{array}$ & $\begin{array}{l}8.40 \\
6.83 \\
7.27 \\
9.31 \\
5.74\end{array}$ & & $\begin{array}{l}0.549 \\
0.563 \\
0.553 \\
0.558 \\
0.538\end{array}$ & $\begin{array}{l}6.71 \\
6.83 \\
5.78 \\
7.07 \\
8.44\end{array}$ & & $\begin{array}{l}0.558 \\
0.552 \\
0.560 \\
0.545 \\
0.559\end{array}$ & $\begin{array}{l}7.78 \\
4.28 \\
5.16 \\
5.96 \\
7.29\end{array}$ \\
\hline Mean & 0.560 & 7.37 & Mean & 0.547 & 6.93 & Mean & 0.555 & 6.09 \\
\hline \multicolumn{2}{|c|}{$\begin{array}{l}\text { Standard } \\
\text { deviation } \pm 0.015\end{array}$} & \pm 1.34 & \multicolumn{2}{|c|}{$\begin{array}{l}\text { Standard } \\
\text { deviation } \pm 0.016\end{array}$} & \pm 0.92 & \multicolumn{2}{|c|}{$\begin{array}{l}\text { Standard } \\
\text { deviation } \pm 0.006\end{array}$} & \pm 1.30 \\
\hline \multirow[t]{4}{*}{$\begin{array}{l}\text { Standard } \\
\text { deviation } \\
\text { of mean } \pm\end{array}$} & 0.007 & \pm 0.60 & $\begin{array}{l}\text { Standard } \\
\text { deviation } \\
\text { of mean }\end{array}$ & \pm 0.007 & \pm 0.41 & $\begin{array}{l}\text { Standard } \\
\text { deviation } \\
\text { of mean }\end{array}$ & \pm 0.003 & \pm 0.58 \\
\hline & \multicolumn{2}{|c|}{$\begin{array}{l}\text { Grain size . } 84-1.00 \mathrm{~mm} \\
\text { Age: } 384 \mathrm{hr}\end{array}$} & & & & & \multicolumn{2}{|c|}{$\begin{array}{l}\text { Grain size } 1.00+ \\
\text { Age: } 384 \mathrm{hr}\end{array}$} \\
\hline & $\begin{array}{l}\text { Density } \\
\left(\mathrm{g} / \mathrm{cm}^{3}\right)\end{array}$ & $\begin{array}{l}\text { Compressive } \\
\text { strength } \\
\left(\mathrm{kg} / \mathrm{cm}^{2}\right)\end{array}$ & & & & & $\begin{array}{l}\text { Density } \\
\left(\mathrm{g} / \mathrm{cm}^{3}\right)\end{array}$ & $\begin{array}{l}\text { Compressive } \\
\text { strength } \\
\left(\mathrm{kg} / \mathrm{cm}^{2}\right)\end{array}$ \\
\hline & $\begin{array}{l}0.570 \\
0.566 \\
0.542 \\
0.568 \\
0.539 \\
0.557\end{array}$ & $\begin{array}{l}4.76 \\
4.40 \\
3.79 \\
4.04 \\
4.45 \\
4.29\end{array}$ & & & & & $\begin{array}{l}0.561 \\
0.558 \\
0.555 \\
0.549 \\
0.540 \\
0.561\end{array}$ & $\begin{array}{l}5.78 \\
5.04 \\
4.86 \\
5.38 \\
4.57 \\
5.21\end{array}$ \\
\hline $\begin{array}{l}\text { Mean } \\
\text { Standard }\end{array}$ & 0.557 & 4.29 & & & & Mean & 0.554 & 5.14 \\
\hline \multicolumn{2}{|c|}{$\begin{array}{l}\text { Standard } \\
\text { deviation } \pm 0.014\end{array}$} & \pm 0.34 & & & & \multicolumn{2}{|c|}{$\begin{array}{l}\text { Standard } \\
\text { deviation } \pm 0.007\end{array}$} & \pm 0.38 \\
\hline $\begin{array}{l}\text { Standard } \\
\text { deviation } \\
\text { of mean } \pm\end{array}$ & & \pm 0.15 & & & & $\begin{array}{l}\text { Standard } \\
\text { deviation } \\
\text { of mean }\end{array}$ & \pm 0.003 & \pm 0.17 \\
\hline
\end{tabular}


Table AV. Series E. Unconfined compressive strength as a function of depth and density of snow cylinders.

Depth below

$(\mathrm{m}) \quad\left(\mathrm{g} / \mathrm{cm}^{3}\right) \quad \begin{array}{ll}\text { Strength } \\ \left(\mathrm{kg} / \mathrm{cm}^{2}\right)\end{array}$

a) Snow pit - Nov. 1960

$\begin{array}{rl}.20 & .378 \\ .20 & .384 \\ .30 & .393 \\ .37 & .389 \\ .55 & .374 \\ .84 & .300 \\ .84 & .393 \\ 1.05 & .393 \\ 1.20 & .426 \\ 1.37 & .381\end{array}$

b) Snow mine - 1957

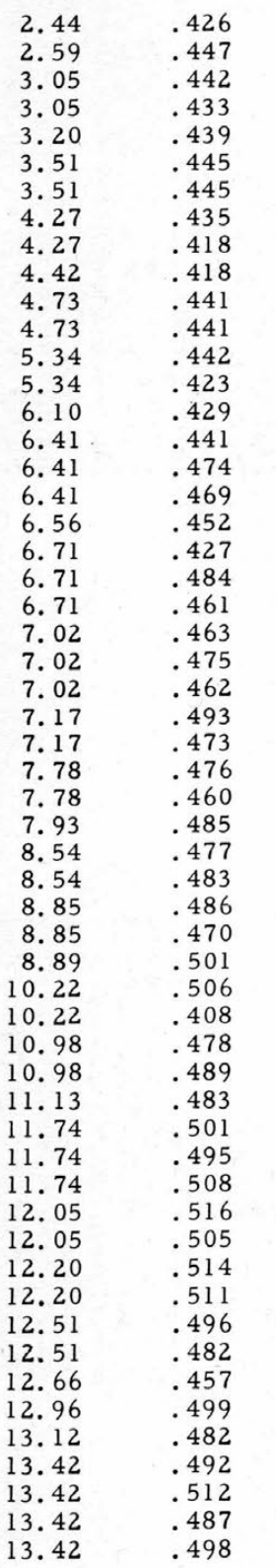

.23
.23
.80
.44
.28
.48
.41
1.16
.81
.53

1.37
1.37
1.60
1.60
1.60
1.80
1.80
1.92
2.14
2.14

2. 06

3. 48

3.20

2. 64

1. 95

3.80

2. 80

3. 15

2. 38

3. 09

2. 50

2. 80

3. 27

3. 70

2. 98

4. 22

5.97

5. 60

4. 75

3.96

8. 53

5.91

5. 70

5. 04

7.39

7. 50

7. 18

8. 29

5.91

6. 63

6.73

7. 61

7. 76

6. 17

9. 71

8. 59

8. 58

6. 73

9.66

11.70

13. 55

11.16

14.53

14.65

14.79

15.83

12. 65

8.28

10.09

8.17

11. 10

9. 59

11. 71

14.43

9.88

12. 00

14.03

14.03

14.03
14.34

14.49

14.49

14.64

14.64

14.64

14.79

14.95

15. 10

15.10

15. 25

15. 25

15. 40

15.55

15.86

15.86

15.86

16.01

16.01

16. 17

16.17

16. 32

16. 47

16. 47

17.08

17.08

17.08

17.54

17.69

18.00

18. 30

18. 61

18.91

18. 91

19.06

19.22

19.37

19.52

19.52

19.67

19.83

19.98

20.13

20.13

20. 44

20. 44

20. 74

20. 74

20.89

21.05

21. 20

21.35
Depth below

$\begin{array}{cl}\text { surface } & \text { Density } \\ (\mathrm{m}) & \left(\mathrm{g} / \mathrm{cm}^{3}\right)\end{array}$

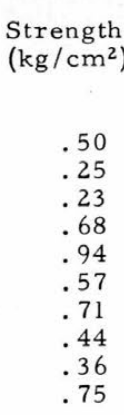

$14.03 \quad .513$

$$
\begin{array}{r}
.404 \\
.394 \\
.373 \\
.413 \\
.411 \\
.406 \\
.398 \\
.398 \\
.385 \\
.360
\end{array}
$$

.513
.501

.505

.505

.505

.524

.530

.510

.517

.513

.517

.505

.517

.516

.492

.501

.508

.504

.528

.537

.540

.521

. 507

.522

.540

.530

.524

.527

.526

.536

.529

.519

.535

.566

.537

.543

539

.551

.541

.560

.543

.550

.540

.556

.549

.540

.545

.553

.558

.560

.545

.554

.556

.558

.548

.560
10.09

12. 11

12. 21

12.36
14.00

14. 43

16. 05

14.23

14. 14

12. 31

16.86

13.52

15. 09

15. 44

10.92

10.82

13. 22

13. 52

16.46

15. 44

18. 57

15.36

12. 67

14.53

17.21

16. 25

15.06

13. 55

12. 72

14.63

13.53

16. 30

14. 74

20. 99

15. 82

17.97

15. 76

18. 95

20. 69

22. 77

18. 09

18.27

12. 04

21.85

19. 28

15. 44

16.67

19. 58

17.92

17. 76

20. 38

21.50

18. 97

21.00

18.37

16.65

Depth below

$\begin{array}{ccc}\begin{array}{c}\text { surface } \\ (\mathrm{m})\end{array} & \begin{array}{c}\text { Density } \\ \left(\mathrm{g} / \mathrm{cm}^{3}\right)\end{array} & \begin{array}{c}\text { Strength } \\ \left(\mathrm{kg} / \mathrm{cm}^{2}\right)\end{array}\end{array}$

$\begin{array}{lll}2.35 & .362 & .23 \\ 2.35 & .365 & .41 \\ 2.63 & .413 & .57 \\ 2.89 & .374 & .50 \\ 3.05 & .386 & .62 \\ 3.05 & .399 & .52 \\ 3.37 & .387 & .64 \\ 3.37 & .388 & .46 \\ 3.60 & .441 & 1.53 \\ 3.60 & .440 & 1.85\end{array}$

\subsection{5}

.567

14.50

$\begin{array}{lll}21.66 & .523 & 15.75\end{array}$

$\begin{array}{lll}21.66 & .534 & 12.77\end{array}$

$\begin{array}{lll}21.81 & .545 & 18.87\end{array}$

$\begin{array}{lll}21.96 & .551 & 21.99\end{array}$

$\begin{array}{lll}21.96 & .565 & 20.79\end{array}$

$\begin{array}{lll}22.27 & .574 & 23.26\end{array}$

$\begin{array}{lll}22.27 & .569 & 16.65\end{array}$

$\begin{array}{lll}22.27 & .562 & 17.97\end{array}$

$\begin{array}{lll}22.42 & .559 & 21.80\end{array}$

$\begin{array}{lll}22.57 & .556 & 16.15\end{array}$

$\begin{array}{lll}22.57 & .562 & 19.45\end{array}$

$\begin{array}{lll}22.57 & .563 & 18.27\end{array}$

$\begin{array}{lll}27.72 & .547 & 20.49\end{array}$

$\begin{array}{lll}22.88 & .550 & 19.43\end{array}$

$\begin{array}{lll}23.03 & .567 & 20.89\end{array}$

$\begin{array}{lll}23.03 & .561 & 25.79\end{array}$

$\begin{array}{lll}23.18 & .560 & 18.45\end{array}$

$\begin{array}{lll}23.18 & .560 & 15.23\end{array}$

$\begin{array}{lll}23.33 & .559 & 21.09\end{array}$

$\begin{array}{lll}23.49 & .564 & 22.56\end{array}$

$\begin{array}{lll}23.64 & .569 & 21.75\end{array}$

$\begin{array}{lll}23.64 & .579 & 19.08\end{array}$

$\begin{array}{lll}23.79 & .566 & 14.74\end{array}$

$\begin{array}{lll}23.94 & .580 & 28.11\end{array}$

$\begin{array}{lll}24.10 & .566 & 26.65\end{array}$

$\begin{array}{lll}24.25 & .580 & 27.05\end{array}$

$\begin{array}{lll}24.25 & .567 & 22.31\end{array}$

$\begin{array}{lll}24.40 & 561 & 20.09\end{array}$

$\begin{array}{lll}24.40 & .566 & 22.91\end{array}$

$24.40 \quad .562 \quad 21.12$

$24.55-566-25.13$

$\begin{array}{lll}24.55 & .562 & 28.46\end{array}$

$\begin{array}{lll}24.71 & .563 & 22.71\end{array}$ 

AD
Accession No.

U. S. Army Cold Regions Research and Engineering Laboratory, Army Materiel Command, Hanover, N.H. AGE HARDENING OF SNOW AT THE SOUTH POLEAnthony J. Gow, and René O. Ramseier

Research Report 112, Nov 1964, 19p-illus.-table-app. DA Task 8X99-27-001-03

Unclassified Report

The age hardening of artificially and naturally compacted snow has been investigated at the South Pole.

Results show that the age-hardening process is greatly retarded at low temperatures. Artificially compacted samples of density $0.55 \mathrm{~g} / \mathrm{cm}^{3}$ attained a compressive strength of less than $3.0 \mathrm{~kg} / \mathrm{cm}^{2}$ after one year's aging at - 9 . Exposure to solar radiation accelerated the age hardening. Irradiated samples attained a strengt m. maximum of $8.0 \mathrm{~kg} / \mathrm{cm}^{2}$ at the end of $600 \mathrm{hr}$. Com pressive strengths increased with decrease in snowparticle size and with increasing angularity of the part cles. Below $\mathrm{m}$ the strength of naturally compacted snow was found to increase rapidly with increase in density. Naturally compacted snow of density 0.55 $\mathrm{g} / \mathrm{cm}^{3}$ possessed considerably greater strength than a of the age-hardened samples of artificially compacted

AD Accession No.

U. S. Army Cold Regions Research and Engineering Laboratory, Army Materiel Command, Hanover, N.H. AGE HARDENING OF SNOW A T THE SOUTH POLEAnthony J. Gow, and René O. Ramseier

Research Report 112, Nov 1964, 19p-illus. -table-app. DA. Task 8X99-27-001-03

Unclassified Report

The age hardening of artificially and naturally compacted snow has been investigated at the South Pole Results show that the age-hardening process is greatly retarded at low temperatures. Artificially compacted samples of density $0.55 \mathrm{~g} / \mathrm{cm}^{3}$ attained a compressive strength of less than $3.0 \mathrm{~kg} / \mathrm{cm}^{2}$ after one year's aging at $-49 \mathrm{C}$. Exposure to solar radiation accelerated the age hardening. Ir radiated samples attained a strength of $6.0 \mathrm{~kg} / \mathrm{cm}^{2}$ after $100 \mathrm{hr}$, increasing to a virtual maximum of $8.0 \mathrm{~kg} / \mathrm{cm}^{2}$ at the end of $600 \mathrm{hr}$. Compressive strengths increased with decrease in snowparticle size and with increasing angularity of the particles. Below $3 \mathrm{~m}$ the strength of naturally compacted snow was found to increase rapidly with increase in density. Naturally compacted snow of density 0.55 $\mathrm{g} / \mathrm{cm}^{3}$ possessed considerably greater strength than an of the age-hardened samples of artificially compacted (over)

\section{UNC LASSIFIED}

1. Snow (Construction Material)

2. Snow--Strength-Measurement

3. Snow samplers-Antarctic regions Gow, Anthony J.

II. Ramseier, René O.

III. U. S. Army Cold Regions Research and Engineer ing Laboratory

\section{UNC LASSIFIED}

1. Snow (Construction Material)

2. Snow--Strength-Measurement

3. Snow samplers-Antarctic region

I. Gow, Anthony J

II. Ramseier, René O.

III. U. S. Army Cold Regions Research and Enginee ing Laboratory
$\mathrm{AD}$

Accession No.

U. S. Army Cold Regions Research and Engineering Laboratory, Army Materiel Command, Hanover, N.H. AGE HARDENING OF SNOW AT THE SOUTH POLEAnthony J. Gow, and René O. Ramseier

Research Report 112, Nov 1964, 19p-illus. -table-app. DA Task 8X99-27-001-03

Unclassified Report

The age hardening of artificially and naturally compacted snow has been investigated at the South Pole.

Results show that the age-hardening process is greatl retarded at low temperatures. Artificially compacted samples of density $0.55 \mathrm{~g} / \mathrm{cm}^{3}$ attained a compressive strength of less than $3.0 \mathrm{~kg} / \mathrm{cm}^{2}$ after one year's aging at $-49 \mathrm{C}$. Exposure to solar radiation accelerated the a age hardeni $\mathrm{cm}^{2}$ fter $100 \mathrm{hr}$, increasing to a virtual maximum of $8.0 \mathrm{~kg} / \mathrm{cm}^{2}$ at the end of $600 \mathrm{hr}$. pressive strengths increa presticle size and with increasing angularity of the particles. cles. Below 3 the strength of snow was found to increase rapidy with increase in d ${ }^{3}$ pos g/cm possessed considerably greater strength than an of the age-hardened samples of artificially compacted

AD
(over)

$\mathrm{AD}$

Accession No.

U. S. Army Cold Regions Research and Engineering Laboratory, Army Materiel Command, Hanover, N.H. AGE HARDENING OF SNOW AT THE SOUTH POLEAnthony J. Gow, and René O. Ramseier

Research Report 112, Nov 1964, 19p-illus. -table-app. DA Task 8X99-27-001-03

Unclassified Report

The age hardening of artificially and naturally compacted snow has been investigated at the South Pole. Results show that the age-hardening process is greatly retarded at low temperatures. Artificially compacted samples of density $0.55 \mathrm{~g} / \mathrm{cm}^{3}$ attained a compressive strength of less than $3.0 \mathrm{~kg} / \mathrm{cm}^{2}$ after one year's agin at -49C. Exposure to solar radiation accelerated the age hardening. Ir radiated samples attained a strength of $6.0 \mathrm{~kg} / \mathrm{cm}^{2}$ after $100 \mathrm{hr}$, increasing to a virtual maximum of $8.0 \mathrm{~kg} / \mathrm{cm}^{2}$ at the end of $600 \mathrm{hr}$. Com- pressive strengths increased with decrease in snowparticle size and with increasing angularity of the particles. Below $3 \mathrm{~m}$ the strength of naturally compacted snow was found to increase rapidly with increase in density. Naturally compacted snow of density 0.55 $\mathrm{g} / \mathrm{cm}^{3}$ possessed considerably greater strength than an of the age-hardened samples of artificially compacted
UNC LASSIFIED

1. Snow (Construction Material)

2. Snow--Strength-Measurement

3. Snow samplers-Antarctic regions

I. Gow, Anthony J.

II. Ramseier, René O.

III. U. S. Army Cold Regions Research and Engineering Laboratory

\section{UNC LASSIFIED}

1. Snow (Construction Material)

2. Snow--StrengthMeasurement

3. Snow samplers-Antarctic region

I. Gow, Anthony J.

II. Ramseier, René O.

II. U. S. Army Cold Regions Research and Engineering Laboratory 


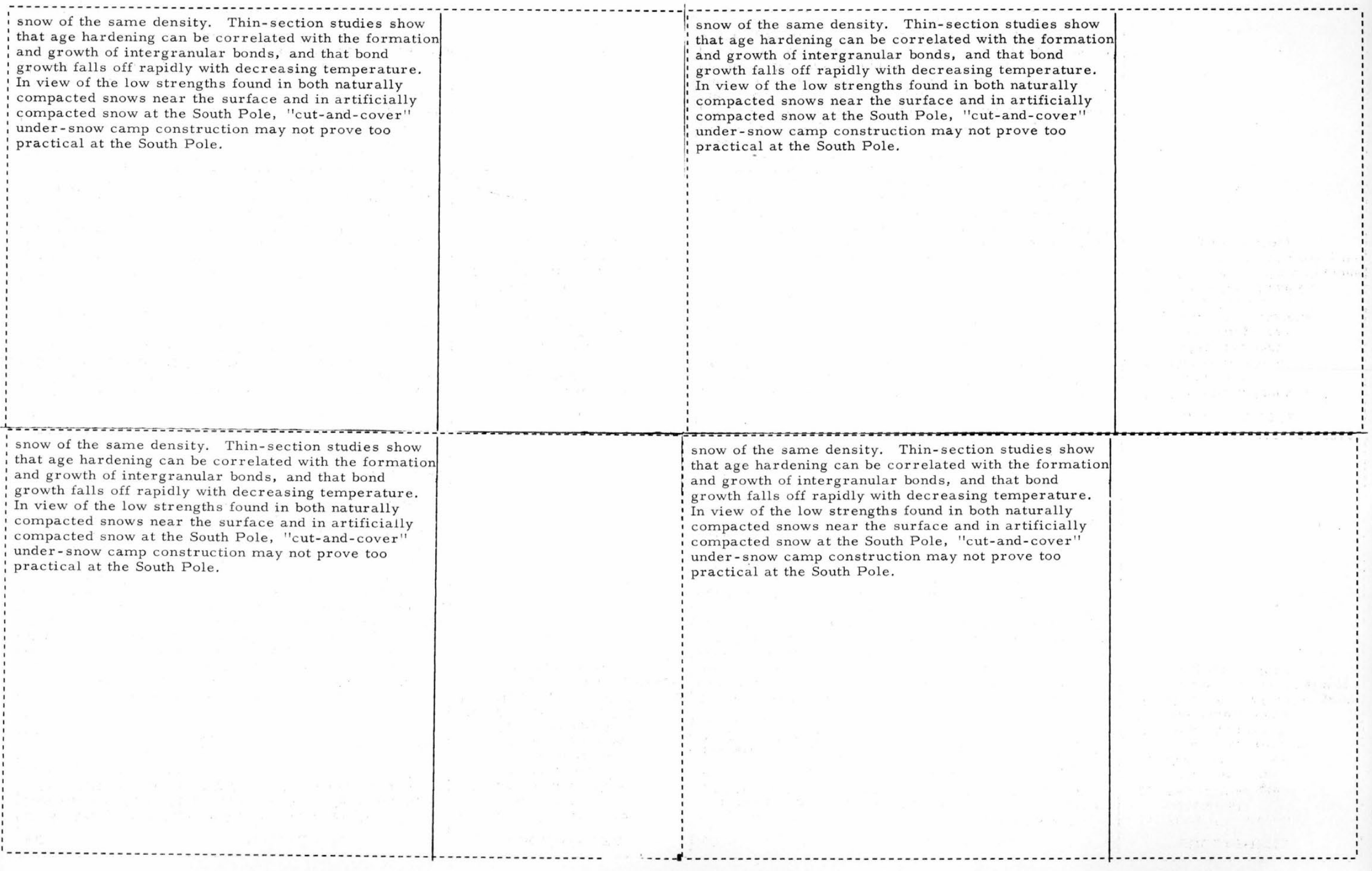

